\title{
Evidence of cellular senescence during the development of estrogen-induced pituitary tumors
}

\author{
Maria Eugenia Sabatino, Juan Pablo Petiti, Liliana del Valle Sosa, Pablo Anibal Pérez, \\ Silvina Gutiérrez, Carolina Leimgruber, Alexandra Latini ${ }^{1}$, Alicia Inés Torres and \\ Ana Lucía De Paul \\ Facultad de Ciencias Médicas, Instituto de Investigaciones en Ciencias de la Salud (INICSA-CONICET), \\ Centro de Microscopía Electrónica, Universidad Nacional de Córdoba, Av. Enrique Barros y Enfermera Gordillo, \\ Ciudad Universitaria, 5000 Córdoba, Argentina \\ ${ }^{1}$ Laboratorio de Bioenergética y Estrés Oxidativo, Departamento de Bioquímica, Centro de Ciencias Biológicas,
} Universidad Federal de Santa Catarina, Florianópolis, Brazil

Correspondence should be addressed to A L De Paul

Email

adepaul@cmefcm.uncor.edu

\begin{abstract}
Although pituitary adenomas represent $25 \%$ of intracranial tumors, they are usually benign, with the mechanisms by which these tumors usually avoid an invasive profile and metastatic growth development still remaining unclear. In this context, cellular senescence might constitute a plausible explanation for the benign nature of pituitary adenomas. In this study, we investigated the emergence of cellular senescence as a growth control mechanism during the progression of estrogen-induced pituitary tumors. The quantification of Ki67immunopositive cells in the pituitaries of estrogenized male rats after 10, 20, 40, and 60 days revealed that the mitogenic potential rate was not sustained for the whole period analyzed and successively decreased after 10 days of estrogen exposure. In addition, the expression of cellular senescence features, such as the progressive rise in the enzymatic senescenceassociated b-galactosidase (SA-b-gal) activity, IL6, IL1b, and TGFb expression, was observed throughout pituitary tumor development. Furthermore, tumoral pituitary cells also displayed nuclear pATM expression, indicating activated DNA damage signaling, with a significant increase in p21 expression also being detected. The associations among DNA damage signaling activation, SA-b-gal expression, and p21 may provide a reliable combination of senescence-associated markers for in vivo pituitary senescence detection. These results suggest a role for this cellular process in the regulation of pituitary cell growth. Thus, cellular senescence should be conceived as a contributing component to the benign nature of pituitary adenomas, thereby influencing the capability of the pituitary gland to avoid unregulated cell proliferation.
\end{abstract}
Key Words
- pituitary
- estrogen
- immunohistochemistry
- tumor
- cellular senescence

Endocrine-Related Cancer (2015) 22, 299-317

\section{Introduction}

The pituitary gland is a principal controller of endocrine homeostasis. Through the release of specific hormones synthesized by five highly differentiated cells, this gland responds to central and peripheral signals. In spite of presenting low mitogenic and apoptotic rates, the gland exhibits dynamic and plastic fluctuations in reaction to 
exogenous and endogenous stimuli in order to constantly adapt the hormonal and metabolic responses to changing environments (Levy 2002). Nevertheless, several alterations in cell growth can lead to pituitary hyperplasia and high levels of hormone production, frequently related to adenoma formation (Asa \& Ezzat 2009).

Pituitary adenomas represent $25 \%$ of intracranial tumors, with their prevalence rising with age, and both sexes being similarly affected (Asa \& Ezzat 2009). However, despite their relatively common incidence, pituitary tumors are usually benign (Maiza \& Caron 2009). The mechanisms by which these tumors may rarely acquire invasive profile and metastastic growth are unclear, even when oncogenic pathways are triggered or tumor suppressor pathways are inactivated. These particularities of pituitary adenomas have led to the hypothesis that there may be an additional process that acts as a protective anti-proliferative mechanism.

Cellular senescence can be interpreted as a spontaneous initial barrier in tumorigenesis, because senescent cells are abundant within pre-malignant lesions, whereas they rarely appear in malignant tumors (Collado et al. 2005). In this way, senescence renders an impediment against oncogenic stimulation and prevents cellular transformation (Collado \& Serrano 2010). In vitro studies have revealed that certain oncogenic signaling, depending on the context, can paradoxically provoke growth arrest along with a cellular senescent phenotype (Michaloglou et al. 2005). Moreover, emergent evidence has described in vivo premature cellular senescence in the early stages of tumor growth, suggesting that this process could act as a potent anti-tumor protective mechanism that must be overcome for tumor progression (Braig et al. 2005, Collado et al. 2005).

Senescence is considered to be a stress response characterized by permanent cell cycle arrest, which can be triggered by different factors including DNA damage, oxidative stress, telomere dysfunction, aberrant proliferative signals of oncogenes, and the inactivation of tumor suppressor genes (Campisi \& d'Adda di Fagagna 2007). Consistent with cellular arrest, the senescence phenotype is accompanied by the upregulation of different cell-cycle regulators such as the CDK inhibitors $\mathrm{p} 16^{\mathrm{INK} 4 \mathrm{~A}}, \mathrm{p} 15^{\mathrm{INK} 4 \mathrm{~B}}$, p21 ${ }^{\mathrm{CIP} 1}$, among others (Roninson 2002, Holst et al. 2003). Because several senescence-inducing stimuli provoke epigenomic disruption or genomic damage, many senescent cells harbor a persistent DNA damage response (DDR) signaling, such as the activation of the kinase ataxia telangiectasia mutated (ATM) (Di Micco et al. 2006), and the involvement of p53 activation (Rodier et al. 2007). In addition, senescent cells show higher levels of detectable senescence-associated b-galactosidase (SA-b-gal; Dimri et al. 1995, Lee et al. 2006), which can also include compromised mitochondrial dynamics and metabolism (Moiseeva et al. 2009), with unbalanced mitochondrial fusion and fission processes (Lee et al. 2007). In fact, senescent cells undergo extensive gene expression changes that emulate the inflammatory response, thereby developing a complex senescence-associated secretory phenotype (SASP), in vitro and in vivo, associated with the activation of nuclear factor kappa B (NFkB) or C/EBPB (Coppe et al. 2008). SASP proteins include a wide range of growth factors, proteases, chemokines, and cytokines including interleukin 6 (IL6), IL1, transforming growth factor beta (TGFb), IL8, among others, which participate in senescence intercellular signaling, and interact at, or in the immediate vicinity, of the plasma membrane (Coppe et al. 2008, Kuilman et al. 2008, Young \& Narita 2009).

Cellular senescence may constitute a plausible explanation for the benign nature of pituitary adenomas through the existence of an intrinsic predisposition of pituitary cells to limit uncontrolled proliferation through this cellular program. Some recent studies on pituitary tumorigenesis in transgenic mice (Chesnokova et al. 2007, 2008) and SA-b-gal in human pituitary tumor (Chesnokova et al. 2011, Alexandraki et al. 2012) have suggested that cellular senescence could be a significant mediator of growth cessation in these tumors. However, it still remains uncertain whether this cellular response takes place in the absence of direct genetic manipulation or during the development of pituitary proliferative injuries, indicating a possible physiological role for cellular senescence in the modulation of pituitary cell growth.

Appropriate in vivo models are required to achieve a better understanding of senescence during the development of tumors. In this study, we used a previously developed pituitary tumor experimental model, which consists of long-term estrogen administration in rats, and leads to the formation of prolactin (PRL) secretory tumors presenting hyperplasia/hypertrophy, greater vascularity, and the disruption of the reticulin network (Mukdsi et al. 2006, Palmeri et al. 2009). Considering that it has been postulated that estrogen-induced proliferative lesions could increase the ability of cells to generate prime tumorigenic changes (Melmed 2003), our experimental conditions may represent an accurate in vivo model for studying the outcome of pituitary senescence. In this context, the aim of this study was to investigate the emergence of cellular senescence as a growth control mechanism during the progression of estrogen-induced pituitary tumors.

Published by Bioscientifica Ltd 


\section{Materials and methods}

\section{Animals and experimental models}

Three-month-old Wistar strain male rats were maintained at controlled temperature $\left(21 \pm 3{ }^{\circ} \mathrm{C}\right)$ and lighting conditions (14 h light:10 h darkness cycle), with free access to commercial laboratory chow and tap water. Taking into account that exogenous estrogen excess induces pituitary tumors (Asa \& Ezzat 2002, Mukdsi et al. 2004), intact animals were treated with estradiol benzoate (SigmaAldrich) for 10, 20, 40, and 60 days (E10, E20, E40, and E60). Estrogen was implanted subcutaneously in slowreleasing silastic brand capsules (Dow Corning, Medical grade, Midland, MI, USA) filled with $10 \mathrm{mg}$ of estrogen crystals and sealed with silastic cement. The control group was implanted with empty capsules. The rats were decapitated within $10 \mathrm{~s}$ after being removed from their cage, thus avoiding any stress or external stimuli. Fresh pituitary glands were photographed in situ and weighed immediately after collection. The animals were kept in accordance with the Guide for the Care and Use of Laboratory Animals, published by the United States National Institutes of Health (1996), and the experiments were approved by the Institutional Animal Care Committee of the School of Medicine, National University of Córdoba.

\section{Circulating estrogen levels}

Serum estrogen levels were measured by an electrochemiluminescence immunoassay from Roche Diagnostics $\mathrm{GmBH}$, using the commercial Elecsys System 2010 (Elecsys Corporation, Lenexa, KS, USA). For statistical purposes, the serum analyzed was obtained from six rats for each experimental group.

\section{Pituitary cell dissociation}

The protocol for pituitary cell dissociation has been previously described (De Paul et al. 1997). Briefly, rat pituitary glands were placed in the minimal essential medium, and then minced and digested with $0.4 \% \mathrm{w} / \mathrm{v}$ trypsin at constant slow agitation at $37^{\circ} \mathrm{C}$. The cell suspension was gently dispersed using flame-rounded Pasteur pipettes. Cell viability, tested with Trypan blue exclusion, was always better than 90\%. Cell dispersions were transferred to $1.5 \mathrm{ml}$ Eppendorf tubes and centrifuged for $5 \mathrm{~min}$ at $400 \mathrm{~g}$.

\section{Cell culture}

The rat somatolactotroph pituitary adenoma GH3B6 cell line was cultured in HAM-F12 medium (Sigma-Aldrich) supplemented with $5 \% \mathrm{v} / \mathrm{v}$ FCS and $12 \% \mathrm{v} / \mathrm{v}$ horse serum (Invitrogen), as previously described (Petiti et al. 2010). After 3 days of culture and $70 \%$ of confluence in order to recreate estrogenic doses administration at E40-E60, cells were exposed to $17 \mathrm{~b}$-estradiol ( $\mathrm{E}_{2} ; 4 \mathrm{nM}$; Sigma-Aldrich) or vehicle for $120 \mathrm{~h}$ and then submitted to the cytochemical detection of SA-b-gal staining.

\section{Cell cycle analysis}

Dispersed pituitary cells from control and estrogenized animals were fixed in $70 \% \mathrm{v} / \mathrm{v}$ ice-cold ethanol by gentle vortexing. After centrifugation ( $400 \boldsymbol{g}$ for $5 \mathrm{~min}$ ), pellets were washed with citrate-phosphate buffer of $\mathrm{pH}$ 7.8. Finally, the cells were incubated with RNAse (ribonuclease A $0.7 \mathrm{mM}$; Sigma-Aldrich) at $37^{\circ} \mathrm{C}$ for $30 \mathrm{~min}$, and stained with propidium iodide ( $75 \mu \mathrm{M}$; Sigma-Aldrich) for $1 \mathrm{~h}$. The fluorescence intensity was analyzed by flow cytometry using a BD FACS Canto II, and cell cycle analysis of the DNA content was performed using ModFit LT Program (Verity Software, Verity Software House, Topsham, ME, USA). For statistical purposes, cellular dispersions from nine animals of each experimental group were analyzed.

\section{Cytochemical detection of SA-b-gal staining}

SA-b-gal-positive cells were detected by using a b-gal staining kit (Senescence Cell Staining Kit, Sigma-Aldrich), one of the most extended staining methods for cellular senescence mentioned in the bibliography (Dimri et al. 1995, Lee et al. 2006). Briefly, pituitary cryosections (8 $\mu \mathrm{m}$ thickness) were fixed in a mixture containing $2 \% \mathrm{v} / \mathrm{v}$ formaldehyde and $0.2 \% \mathrm{v} / \mathrm{v}$ glutaraldehyde in PBS for $7 \mathrm{~min}$. After washing, the staining solution was added according to the manufacturer's instructions and cryosections were incubated at $37^{\circ} \mathrm{C}$ in a warm room for $20 \mathrm{~h}$. Pituitary sections were mounted and examined under light microscope and photographed at $100 \times$, with only senescent cells staining in blue at a $\mathrm{pH}$ of 6.0. In order to determine the senescent cell index, dispersed pituitary cells from control and estrogenized animals, as well as control and estrogen-stimulated tumoral GH3B6 cells, were subjected to the same SA-b-gal staining procedure and counted in a Neubauer chamber. Rat kidney was used as positive control and the same reaction, but omitting the substrate, served as negative controls. For statistical purposes, randomly chosen visual fields photographed at $400 \times$ and 2000 cells were counted for each cell dispersion for all experimental groups in triplicate.

Published by Bioscientifica Ltd. 
Also, with the purpose of determining the double localization of SA-b-gal/Ki67 and SA-b-gal/PRL into the pituitary parenchyma, after performing the cytochemical detection of SA-b-gal staining, the same pituitary cryosections were processed by immunocytochemistry with monoclonal anti-Ki67 antibody (1:50; BD Pharmingen, Oxford, UK) or rabbit polyclonal anti-PRL (1:4000; NIH Hormone Program, Bethesda, MD, USA, USA), as referred to in the next section.

\section{Immunocytochemistry}

Paraffin-embedded pituitary glands were processed by immunocytochemistry for phosphorylated ATM (pATM), p53, and Ki67. The sections ( $3 \mu \mathrm{m}$ thickness) were treated with $3 \% \mathrm{v} / \mathrm{v}$ hydrogen peroxide in methanol for $30 \mathrm{~min}$ to inhibit endogenous peroxidase, followed by an antigen retrieval method using a hot antigen unmasking solution (0.01 M citrate buffer; $\mathrm{pH}$ 6.0). Then, sections were incubated for $30 \mathrm{~min}$ in $10 \% \mathrm{v} / \mathrm{v}$ normal serum (Sigma-Aldrich) to block nonspecific binding, which was followed by overnight incubation with anti-Ki67 (1:50), rabbit polyclonal anti-p53 (1:200; Santa Cruz), or mouse monoclonal anti-pATM (1:750; Abcam, Cambridge, UK) at $4{ }^{\circ} \mathrm{C}$ in a humidifier chamber. The sections were then incubated with biotinylated secondary antibodies and $\mathrm{ABC}$ complex, with staining carried out using 3,3'-diaminobenzidine tetrahydrochloride as a cromogen, according to the manufacturer's instructions (Sigma-Aldrich). Diaminobenzidine (Sigma-Aldrich) was utilized as the chromogenic substrate for $10 \mathrm{~min}$ at room temperature, and the sections were rinsed in running water, with hematoxylin being used as the counterstain (SigmaAldrich). Controls were performed by applying the same protocol, but omitting primary antibodies. The slides from three animals of each experimental condition were photographed in randomly chosen fields at $400 \times$, with more than 2000-immunoreactive cells being examined. The Ki67, p53, and pATM labeling indexes were determined using NIH Image J Software (National Institutes of Health, Bethesda, MD, USA), and the number of positively stained nuclei was recorded along with the total nuclei.

Also, to assess colocalization of PRL/p21, PRL/Ki67, PRL/p53, and PRL/pATM, additional sets of slides from different experimental conditions were processed for confocal laser scanning microscopy. Paraffin-embedded pituitary sections were processed as mentioned before, but including incubation for $1 \mathrm{~h}$ in $70 \% \mathrm{v} / \mathrm{v}$ ethanol supplemented with $0.25 \% \mathrm{v} / \mathrm{v} \mathrm{NH}_{3}$, while rehydrating the deparaffinized sections in graded alcohol in order to reduce autofluorescence (Baschong et al. 2001). Then, pituitary sections were incubated with anti-PRL (1:4000), anti-Ki67 (1:50), antipATM (1:750), anti-p21 (1:50; Santa Cruz), or p53 (1:300) for $1 \mathrm{~h}$. These slices were washed, and further incubated with Alexa 647 anti-rabbit or Alexa 594 anti-mouse secondary antibodies (1:1000; Invitrogen) for $1 \mathrm{~h}$. The images were then obtained using an inverted FluoView FV 1000 confocal laser scanning microscope (Olympus) and were collected with a $60 \times$ objective. The analysis of confocal microscopy images was carried out using FV10-ASW 1.6 Viewer Software (Olympus Inc., Olympus, Hamburg, Germany).

\section{Ultrastructural immunogold labeling}

The subcellular localization of p21 and pATM in pituitaries was determined by a immuno-electron-microscopy postembedding protocol as previously reported (Sabatino et al. 2013). In brief, pituitary glands were embedded in LR-White (London Resin Corporation, Berkshire, UK), and thin sections were incubated overnight on a drop of anti-p21 or anti-pATM antiserum, which was diluted 1:100. Immunoreactive sites were labeled with anti-mouse secondary antibody conjugated to $15 \mathrm{~nm}$ colloidal gold particles (1:30; Electron Microscopy Sciences, Hatfield, PA, USA). Then, to validate the specificity of the immunostaining, negative controls were performed, and the primary antibodies were replaced with either $1 \% \mathrm{w} / \mathrm{v}$ BSA in PBS or diluted preimmune serum followed by the corresponding secondary antibody. Finally, sections were stained with an aqueous uranyl acetate saturate solution, and examined under a Zeiss LEO 906-E electron microscope and photographed using a Megaview III camera.

Also, the effect of estrogen as an inducer of pituitary tumor development was documented in semithin sections from epoxy resin-embedded glands by high-resolution light microscopy. With this aim, pituitaries from control and E60 were fixed in a mixture of $4 \% \mathrm{v} / \mathrm{v}$ formaldehyde and $2 \% \mathrm{v} / \mathrm{v}$ glutaraldehyde in $0.1 \mathrm{M}$ cacodylate buffer for $2 \mathrm{~h}$ and then treated with $1 \% \mathrm{OsO}_{4}$ before being blockstained with $1 \% \mathrm{v} / \mathrm{v}$ uranyl acetate, as previously described (De Paul et al. 2009). After dehydration with a series of graded cold acetones, glands were embedded in Araldite. The semithin sections $(200 \mathrm{~nm})$ were cut using a JEOL ultramicrotome with a diamond knife, stained with Toluidine blue, and examined using a Zeiss Axiostar Plus light microscope (Oberkochen, Germany).

\section{Subcellular fractionation}

The nuclear and cytoplasmic extracts from control and estrogen-treated rat pituitary glands were prepared

Published by Bioscientifica Ltd 
according to the method of Sugawara et al. (1993) with modifications (Mukdsi et al. 2004). Briefly, three pituitaries per experimental group (from a total of three independent experiments) were minced and homogenized $\left(4^{\circ} \mathrm{C}\right)$ with a teflon glass Potter Elvehjem tissue grinder in $2 \mathrm{ml} 0.3 \mathrm{M}$ sucrose, $1 \mathrm{mM}$ EDTA, $1 \mathrm{mM}$ phenylmethylsulphonyl fluoride, and $10 \mathrm{mM}$ HEPES/KOH ( $\mathrm{pH}$ 7.5). The homogenate was centrifuged at $1000 \mathrm{~g}$ for $10 \mathrm{~min}$, and the supernatant was aliquoted and stored at $-20^{\circ} \mathrm{C}$ until required for cytoplasmic protein quantifications. The pellet containing the nuclear fraction was resuspended in $2 \mathrm{ml}$ solution of $0.3 \mathrm{M}$ sucrose, $1 \mathrm{mM} \mathrm{CaCl}_{2}, 10 \mathrm{mM}$ Tris- $\mathrm{HCl}$ ( $\mathrm{pH}$ 7.5), $1 \mathrm{mM}$ dithiothreitol (DTT), and protease inhibitors. Then, $75 \mu \mathrm{l}$ of $10 \% \mathrm{v} / \mathrm{v}$ Igepal CA630 were added, and the solution was incubated at $4{ }^{\circ} \mathrm{C}$ for $10 \mathrm{~min}$ and centrifuged at $250 \mathrm{~g}$ for $5 \mathrm{~min}$. After washing the pellet once with the same buffer, it was resuspended in two volumes of $20 \mathrm{mM}$ HEPES ( $\mathrm{pH} 7.8$ ), $0.6 \mathrm{M} \mathrm{KCl}$, $0.02 \mathrm{mM} \mathrm{ZnCl}_{2}, 0.2 \mathrm{mM}$ EGTA, $0.5 \mathrm{mM}$ DTT, and protease inhibitors, and incubated at $4{ }^{\circ} \mathrm{C}$ for $30 \mathrm{~min}$. The suspension was centrifuged at $20000 \mathrm{~g}$ at $4{ }^{\circ} \mathrm{C}$ for $30 \mathrm{~min}$, and the aliquots were stored frozen until they were used in western blotting assays.

\section{Western blotting analysis}

The total protein concentration was measured using a BioRad Kit (Bio-Rad Protein Assay, Bio-Rad) and subcellular fractions were run in $12 \% \mathrm{v} / \mathrm{v}$ acrylamide gel. To estimate the corresponding molecular weights, the Full Range Rainbow molecular weight marker was used (Amersham). The membranes were incubated overnight at $4{ }^{\circ} \mathrm{C}$ with the corresponding primary antibody: rabbit polyclonal anti-mitofusin 1 (MFN1) (1:750), rabbit polyclonal antidynamin-related protein 1 (DRP1) (1:500), rabbit polyclonal anti-rat sarcoma (RAS) (1:200), rabbit polyclonal anti TGFb1 (1:300), mouse monoclonal anti-IL6 (1:200), mouse monoclonal anti-p21 (1:200), rabbit polyclonal anti-p53 (1:200), rabbit anti-total ERK1/2 (1:300) (Santa Cruz), rabbit polyclonal anti-NFkB (1:1000), rabbit polyclonal anti-IL1b (1:300) (Abcam), rabbit polyclonal anticytochrome $c$ oxidase subunit 4 (COX4) (1:100), rabbit polyclonal anti-pERK1/2 (1:700) (Cell Signaling Technology, Inc., Boston, MA, USA), mouse monoclonal antib-actin (1:1000), or rabbit polyclonal anti-HDAC1 (1: 500; Sigma-Aldrich). After washing, blots were incubated with a peroxidase-conjugated (HRP) goat anti-rabbit (1:2500) or goat anti-mouse (1:2500) diluted in blocking buffer, rinsed in PBS $/ 0.1 \% \mathrm{v} / \mathrm{v}$ Tween 20 , and revealed with an ECL detection system (Amersham Biosciences). Emitted light was captured on Hyperfilm (Amersham Pharmacia Biotech), and the b-actin, COX4, and HDAC1 antibodies were used as loading controls.

\section{Detection of apoptosis by DNA nick-end labeling}

Nick-end labeling was detected using the TUNEL technique, as previously reported (Palmeri et al. 2009). Pituitary sections fixed on glass slides were processed as stated in the manufacturer's protocol (In Situ Cell Death Detection Kit; Roche). As positive control, the reaction was carried out on DNAse recombinant I ( $6500 \mathrm{U} / \mathrm{ml}$, Invitrogen)-treated sections to induce DNA strand breaks before the labeling procedure. The slides were observed using a Zeiss Axiostar plus microscope at $400 \times$.

\section{Statistical analysis}

The statistical analysis was carried out using an ANOVA with Fisher's post-test (InfoStat version 2004; Grupo InfoStat, Facultad de Ciencias Agropecuarias, Universidad Nacional de Córdoba, Córdoba, Argentina). In order to analyze the binomial proportion data resulting from counting the data of the cytochemichal reactions, a generalized linear mixed modeling procedure of InfoStat Software was utilized with a model that included the fixed effect of treatment (with the logit link function being the default for binomial proportion data). The results were given as the means \pm s.E.M., and the data were obtained from three replicates measured for three independent experiments. The significance levels were chosen at $P<0.05$.

\section{Results}

\section{Estrogen treatment induced pituitary tumor development}

For the purpose of evaluating the cellular senescence during the progression of the experimental pituitary tumors, proliferative lesions were induced in Wistar male rats as previously reported (Mukdsi et al. 2006, Sabatino et al. 2013). For all the periods analyzed: E10, E20, E40, and $\mathrm{E} 60$, the mean values of the serum $\mathrm{E}_{2}$ levels were above $3.7 \mathrm{nM}(4.00 \pm 0.18 \mathrm{nM}$ in $\mathrm{E} 40)$, representing 100 times more than those achieved in control rats $(0.18 \pm 0.01 \mathrm{nM})$. The effect of prolonged estrogen administration on pituitary mass expansion was examined and a significant and progressive increase was observed, with the highest values being obtained at E60 (Fig. 1A). This was also corroborated by the macroscopic observation in sellae,

Published by Bioscientifica Ltd. 

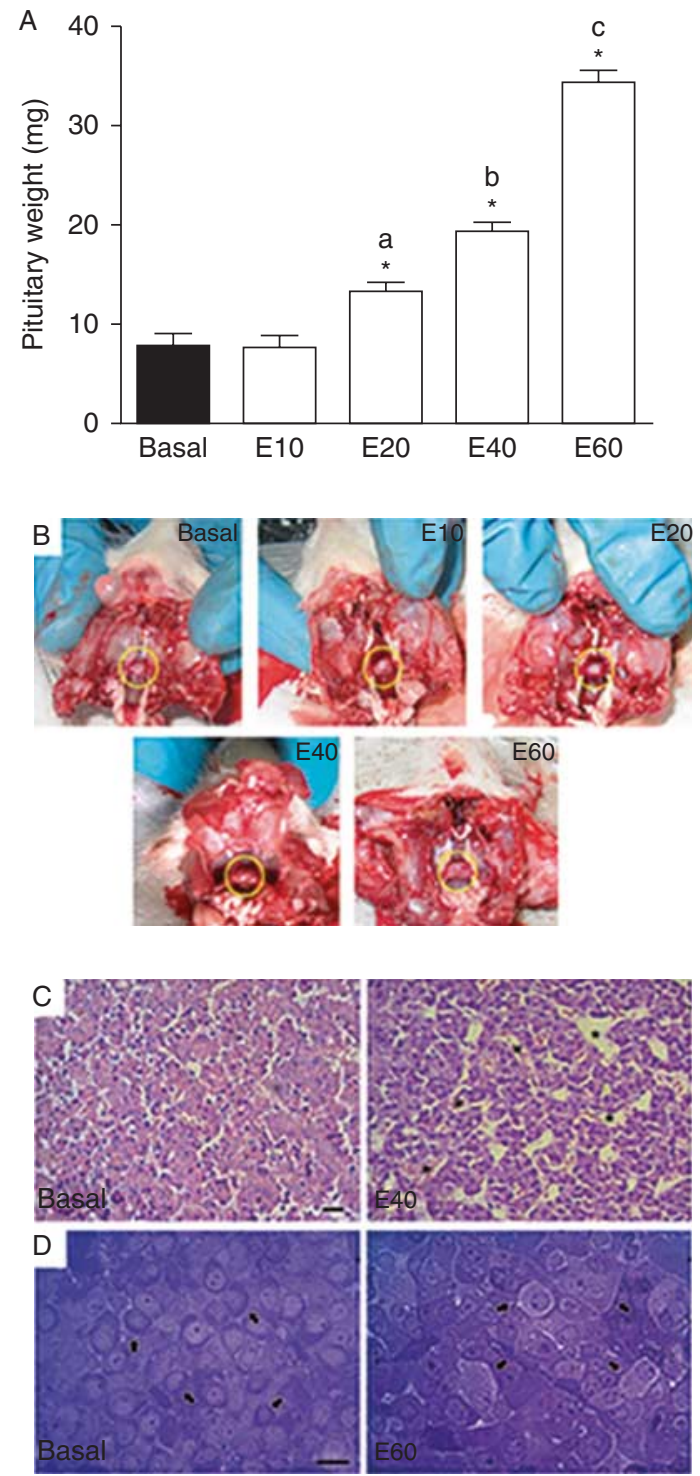

\section{Figure 1}

Rat pituitary expansion after estrogen administration. (A) Pituitary weight (mg) from control (basal) and estrogen-treated rats ( $n=12 /$ group). Results are expressed as means \pm s.E.M.; Fisher's test ( ${ }^{*} P<0.05$ vs basal; means with different letters are statistically different). (B) Photographs of representative in sellae pituitary glands derived from male rats submitted to different periods of tumor development. The pituitary gland sizes are depicted by a circle. (C) Paraffin-embedded adenohypophysis sections from control and estrogen-induced tumoral pituitaries (E40). The parenchyma is surrounded by a network of vascular channels $(*)$, with a marked development in models of sustained stimulation with estradiol benzoate, mainly starting from 40 days of hormone treatment. Staining: H/E. Scale bar: $10 \mu \mathrm{m}$. (D) Micrographs of semithin sections $(200 \mathrm{~nm})$ of Araldite-embedded pituitary gland from control and E60 stained with Toluidine blue. The sustained estrogen exposition provoked a streaking hypertrophy of endocrine cells and hormonal release, as revealed by the lower Toluidine blue staining in the cytoplasms in E60 compared with control cells (arrow). Scale bar: $10 \mu \mathrm{m}$. A full colour version of this figure is available at http://dx.doi.org/10.1530/ERC-14-0333. which revealed a notable size growth compared with normal pituitaries (Fig. 1B). The increase in the pituitary weight was also accompanied by vascular channel enlargement (Fig. 1C), with noticeable cellular hypertrophy being observed by high-resolution light microscopy (Fig. 1D).

Next, we analyzed the time-course changes during the pituitary tumor development by determining the Ki67 labeling index. The quantification of Ki67-immunopositive cells revealed a significant increase in cell proliferation for all time periods analyzed compared with controls, with a peak reached of approximately eightfold higher at E10. In spite of the noteworthy pituitary proliferative response, the estrogen-induced mitogenic potential rate was not sustained for the whole period analyzed and successively decreased after the E10 condition. Interestingly at E60, the proliferative rate exhibited a progressive reduction compared with that attained at E10, with minimal changes observed from E40, which might indicate a plateau phase, although this index still continued to be higher, reaching threefold higher than the control values (Fig. 2A and B).

RAS-deregulated oncogenic signaling induces cellular senescence (Braig et al. 2005, Chen et al. 2005, Collado et al. 2005, Michaloglou et al. 2005). Thus, to determine the contribution of RAS/ERK1/2 signaling during the estrogen-induced pituitary tumor development, their expression levels were analyzed by western blotting. As shown in Fig. 2C, RAS signaling was progressively suppressed, with its expression being less evident at E40E60 than that at baseline conditions of normal pituitaries. When the pERK1/2 protein was analyzed, a similar pattern expression was observed for its phosphorylated form during the development of experimental pituitary tumors.

Finally, to examine whether this decrease in cell proliferation could be due to apoptosis, we also determined the biochemical features of this type of cell death in pituitary cells by the TUNEL method. As shown in Fig. 3, for all experimental groups, the signs of apoptotic nuclei were practically absent with no significant changes in the number of TUNEL-positive cells being detected, thus suggesting that the modifications observed in the growth rate could not have been associated with apoptosis.

\section{Tumoral pituitary cells acquired features of the cellular senescence phenotype}

To try to determine whether cellular senescence takes place during estrogen-induced pituitary tumor development, we turned our attention to the detection of SA-b-gal,

Published by Bioscientifica Ltd. 

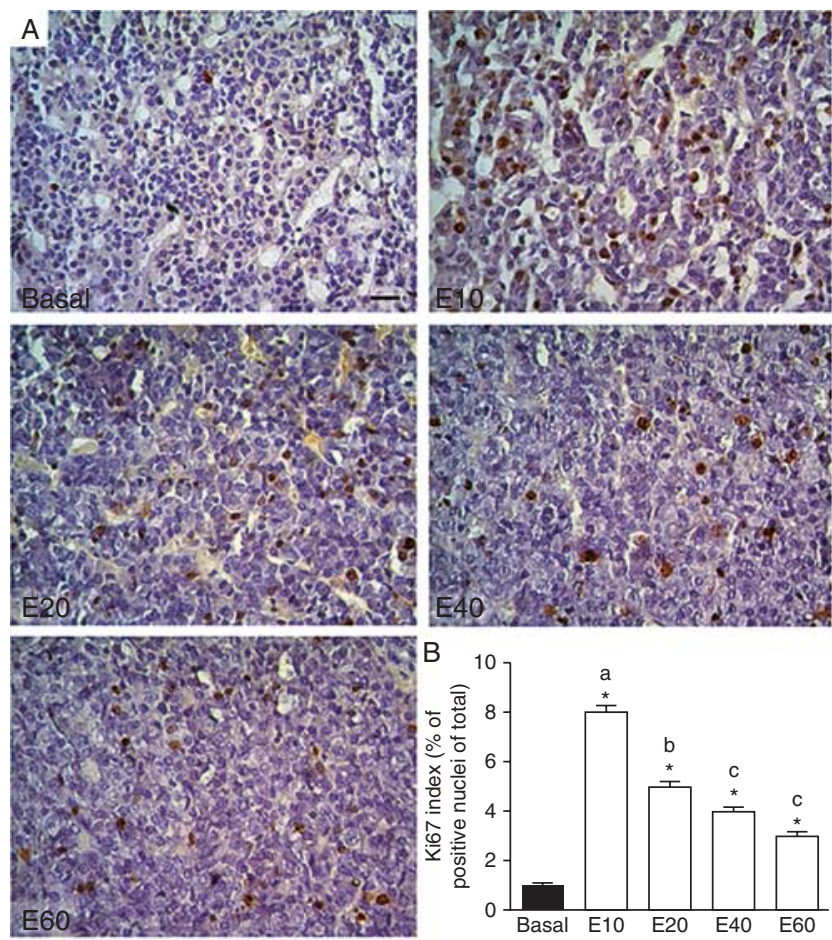

C

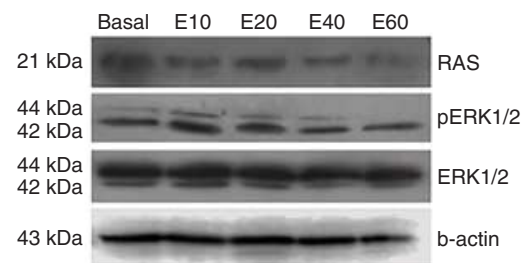

Figure 2

Ki67 immunolabeling in the estrogen-induced pituitary tumors.

(A) Immunocytochemical detection of $\mathrm{Ki67}$ in sections of pituitaries from control and estrogenized rats. A remarkable increase in Ki67 reactivity (brown signal) was seen at the beginning of the proliferative injures. Representative fields of anterior pituitary sections from a representative experiment from a total of three independent experiments with similar results are shown. Scale bar $=20 \mu \mathrm{m}$. (B) The Ki67-positive nuclei staining is expressed as a percentage of the total nuclei counted. Data are expressed as means \pm S.E.M. using the Fisher's test ( ${ }^{*} P<0.05$ vs basal; means with different letters are statistically different). (C) RAS/pERK protein expression during the development of experimental pituitary tumors. Analysis of RAS and pERK $1 / 2$ (total fraction) from control and tumoral pituitary cells by western blotting revealed a RAS/pERK gradual suppression during pituitary tumor development. The b-actin and total ERK1/2 protein expression confirmed equal loading occurring in all lanes. Data are from a representative experiment from a total of three independent experiments with similar results. A full colour version of this figure is available at http://dx.doi.org/10.1530/ERC-14-0333.

and as shown in Fig. 4A a progressive rise in the enzymatic activity was observed. In order to perform a morphometric analysis of these modifications, the SA-b-gal reaction was also developed on dispersed pituitary cells. The SAb-gal-positive cell index revealed a baseline expression at around $7 \%$ of the total pituitary cells, whereas in pituitary tumors a significantly higher number of SA-b-gal-positive cells was observed, with values ranging from almost threefold in the earliest days of the proliferative injury and rising over time until a fivefold increase was recorded at E60 (Fig. 4C).

As it has been previously described that cellular senescence might be overcome in order to develop unregulated cell proliferation (Campisi 2005, Collado \& Serrano 2010), we next evaluated SA-b-gal reactivity in the established GH3B6 pituitary tumor cell line under baseline conditions as well as after sustained estrogen stimulation. As expected, positive cells were scarce, hardly exceeding $1-2 \%$, a value far below those obtained in tumoral pituitaries (Fig. 4B and C).

Hence, during estrogen-induced pituitary tumor development, a cellular senescence process might be emerging, while GH3B6 pituitary tumoral cells rarely become senescent.
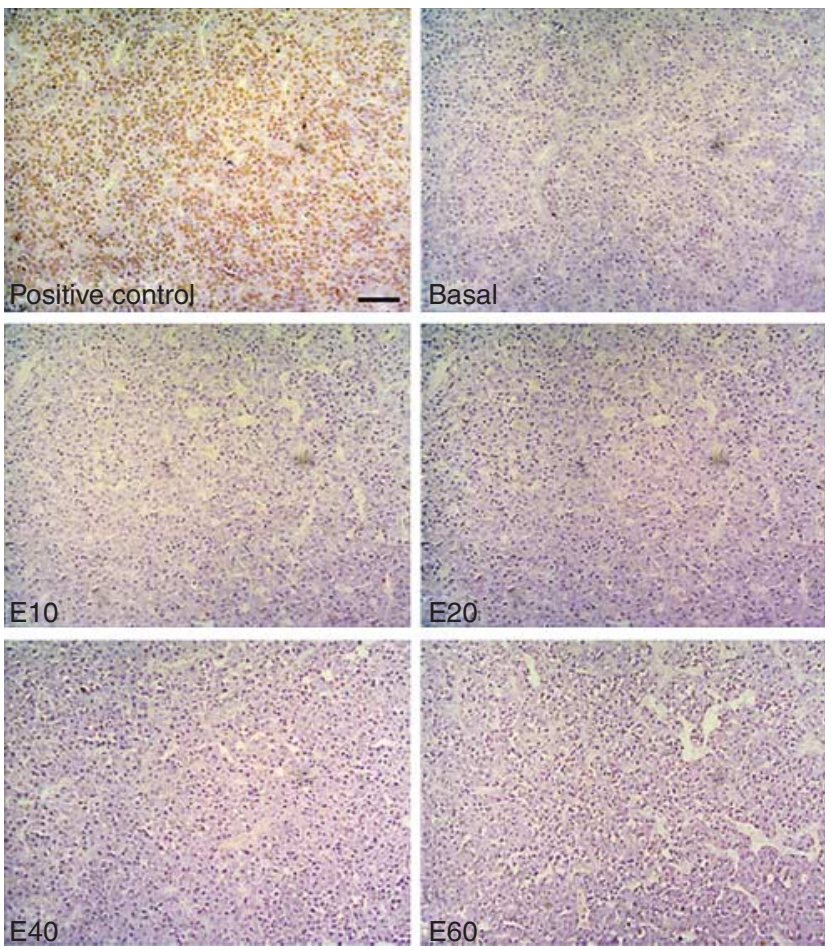

\section{E10}

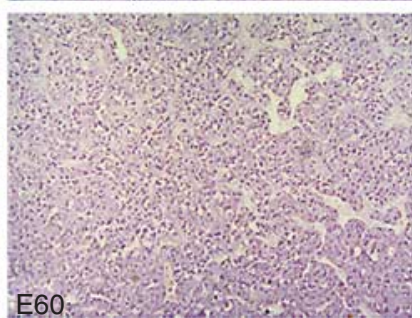

\section{Figure 3}

TUNEL assay on normal and experimental pituitary tumors. No significant detection of biochemical features of apoptosis (brown signal) was detected in histological samples from each experimental condition. Positive control: pituitary gland section treated with DNAase I. Data from a representative experiment for a total of three independent experiments with similar results from each experimental group. Scale bar $=100 \mu \mathrm{m}$. A full colour version of this figure is available at http://dx.doi.org/10.1530/ERC-14-0333.

Published by Bioscientifica Ltd. 

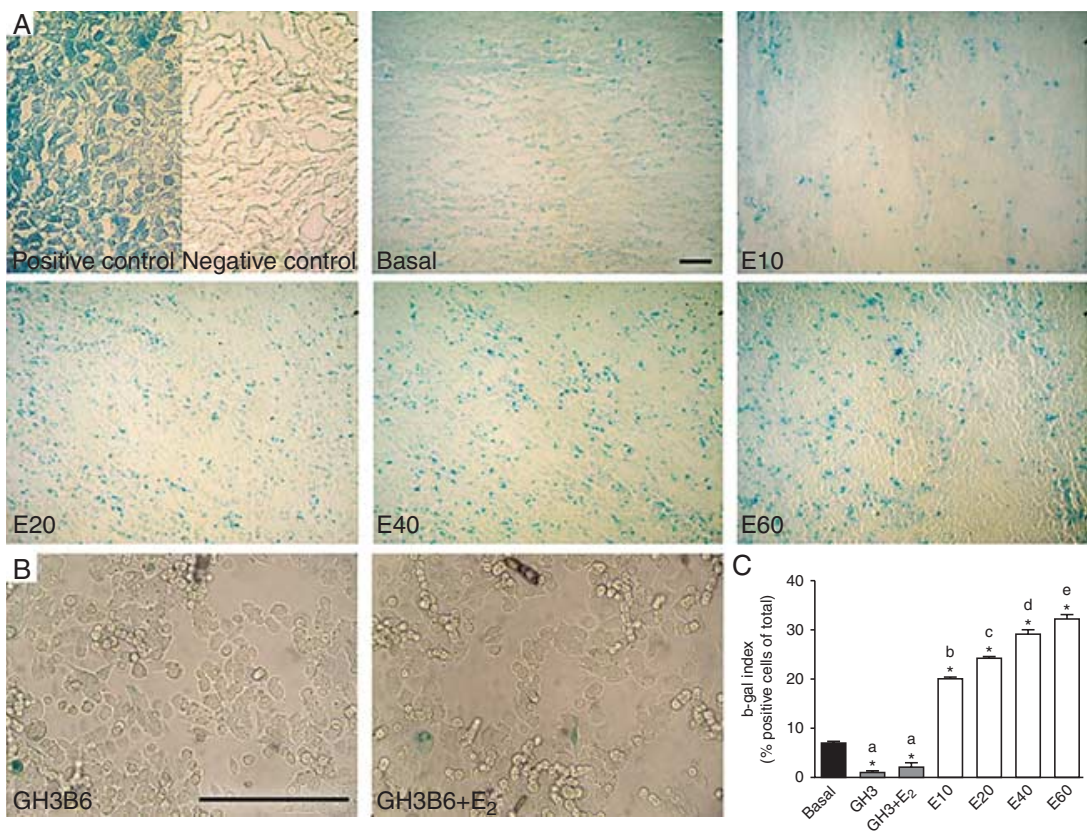

\section{Figure 4}

Senescence features are expressed during pituitary tumor development. (A) Cryosections from normal and tumoral pituitaries showing increases in SA-b-gal reactivity during pituitary tumor development, and GH3B6 cells presenting a low detection of SA-b-gal. The SA-b-gal enzymatic activity is dyed in blue. Positive control, rat kidney and negative control, rat kidney omitting the substrate. Results of a representative experiment are shown. Scale bar $=100 \mu \mathrm{m}$. (B) SA-b-gal reaction in $\mathrm{E}_{2}$-stimulated GH3B6 cells. The cells were cultured with a sustained $E_{2}$ exposition (120 $\left.h ; 4 n M\right)$.

Furthermore, we determined the SA-b-gal reactivity and Ki67 staining in the same cryosection for each experimental condition. As shown in Fig. 5, for all examined conditions, the cellular senescence response was noticeably profuse regarding cell proliferation. By analyzing the joint progression of both biomarkers during the tumoral development, we found that, toward E40 and E60, it was possible to discriminate pituitary parenchyma differential areas in which Ki67-positive cells were predominant, and adjacent zones bore a higher proportion of cells exhibiting the SA-b-gal stain.

To investigate the SASP and involvement of NFkB expression (Kuilman et al. 2008, Freund et al. 2010), next we evaluated IL6, IL1b, TGFb1, and NFkB protein expression levels in pituitary extracts by western blotting. As shown in Fig. 6A, a remarkable increase in IL6 expression levels toward E40 and E60 was detected. In agreement with this result, we also showed increases in IL1b and TGFb1 protein expression levels from E20 to E60 (Fig. 6A). These responses were also accompanied
(C) The number of SA-b-gal-positive cells stained in blue was evaluated and related to the total number of pituitary cells counted for each experimental group. Also, SA-b-gal index from control and estrogen-induced GH3B6 pituitary tumoral cell line was determined. Data were statistically analyzed by the Fisher's test, and the results are expressed as means \pm s.E.M. $(* P<0.05$ vs basal). A full colour version of this figure is available at http://dx.doi.org/ 10.1530/ERC-14-0333.

by a rise in both the cytoplasmic and nuclear NFkB expression, indicating the latter's activation in the context of an experimental pituitary tumor (Fig. 6B). These data indicate that under the present experimental context, inflammatory network activation was triggered for this context together with cellular senescence response.

In order to further characterize the senescence phenotype achieved by tumoral pituitaries, we were also interested in determining whether the mitochondrial dynamics has been compromised, because it was previously reported that mitochondrial dysfunction may facilitate cellular senescence emergence (Moiseeva et al. 2009). Thus, by western blotting, the expression of MFN1 and DRP1 were assessed as indicators of fusion and fission processes respectively. As shown in Fig. 6C, both proteins were affected during the development of experimental pituitary tumors, while MFN1 protein expression was progressively upregulated; the DRP1 expression was notably decreased during in vivo pituitary tumor development.

Published by Bioscientifica Ltd 

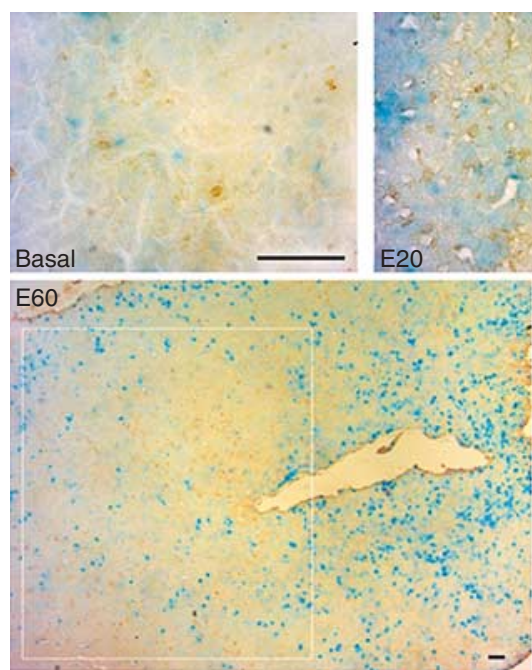
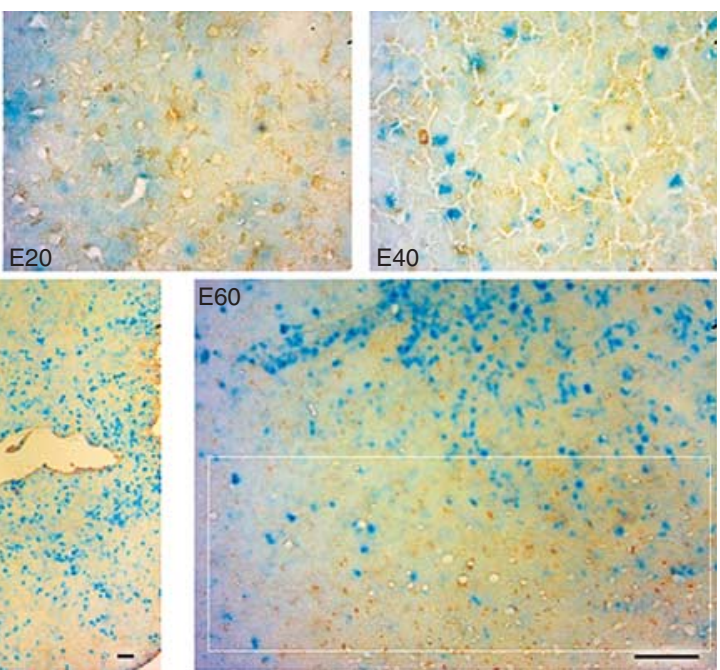

\section{Figure 5}

SA-b-gal and Ki67 staining in cryosections from normal and tumoral pituitaries. For all examined conditions, proliferating cells (white rectangle) did not show any SA-b-gal expression. Results of a

\section{Activated DNA damage signaling, p21 accumulation, and an abnormal cell cycle profile are displayed in experimental pituitary tumors}

The pattern of expression of several key cycle regulators involved in the senescence pathways was examined. Considering that the DDR plays an essential role in the senescence pathways (Di Micco et al. 2006), we aimed to find out if SA-b-gal expression was accompanied by DDR activation.

By immunocytochemistry, a significant increase in the number of pituitary cells displaying nuclear pATM expression was detected in experimental pituitary tumors, reflecting the activation of DNA damage signaling. The pATM signal showed a sustained increase from E10 to E60, with a significant peak of nuclear pATM-positive cells of around 30\% at E40 (Fig. 7A and B). The pATM subcellular
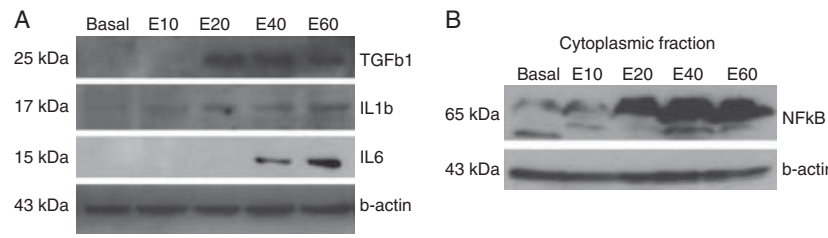

\section{Figure 6}

Senescence features are expressed during pituitary tumor development. Western blotting expression of IL6, IL1b, and TGFb1 (A); NFkB (cytoplasmic and nuclear fractions) (B) and DRP1; MFN1 (total extracts) (C) and from control and tumoral pituitary glands revealed signs associated with representative experiment are shown. Scale bar $=20 \mu \mathrm{m}$. A full colour version of this figure is available at http://dx.doi.org/10.1530/ERC-14-0333.

localization was corroborated by electron microscopy immunogold labeling, which revealed both nuclear and cytoplasmic immunoreactivity in tumoral pituitaries taking place at E40 (Fig. 7C).

The p53 protein, one of the major regulators of cell cycle progression in response to DNA damage or arrest of DNA synthesis, is considered to be an ATM target (Pluquet \& Hainaut 2001). Using immunocytochemistry, an increase in p53 expression was detected for E10 and E20, whereas for $\mathrm{E} 40$ this signal was no longer observed (Fig. 8A). Considering that the p53 function is related to its intracellular localization, we also analyzed p53 subcellular expression by western blotting from nuclear and cytoplasmic pituitary extracts. An important increase in p53 signaling was immunodetected from E20 in the cytosolic compartment of pituitary cells, while a decrease

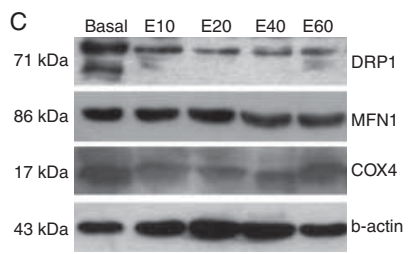

inflammatory network activation and mitochondrial fusion. The b-actin COX4, and HDAC1 protein expressions were used as loading controls. Data are from a representative experiment from a total of three independent experiments with similar results.

Published by Bioscientifica Ltd. 

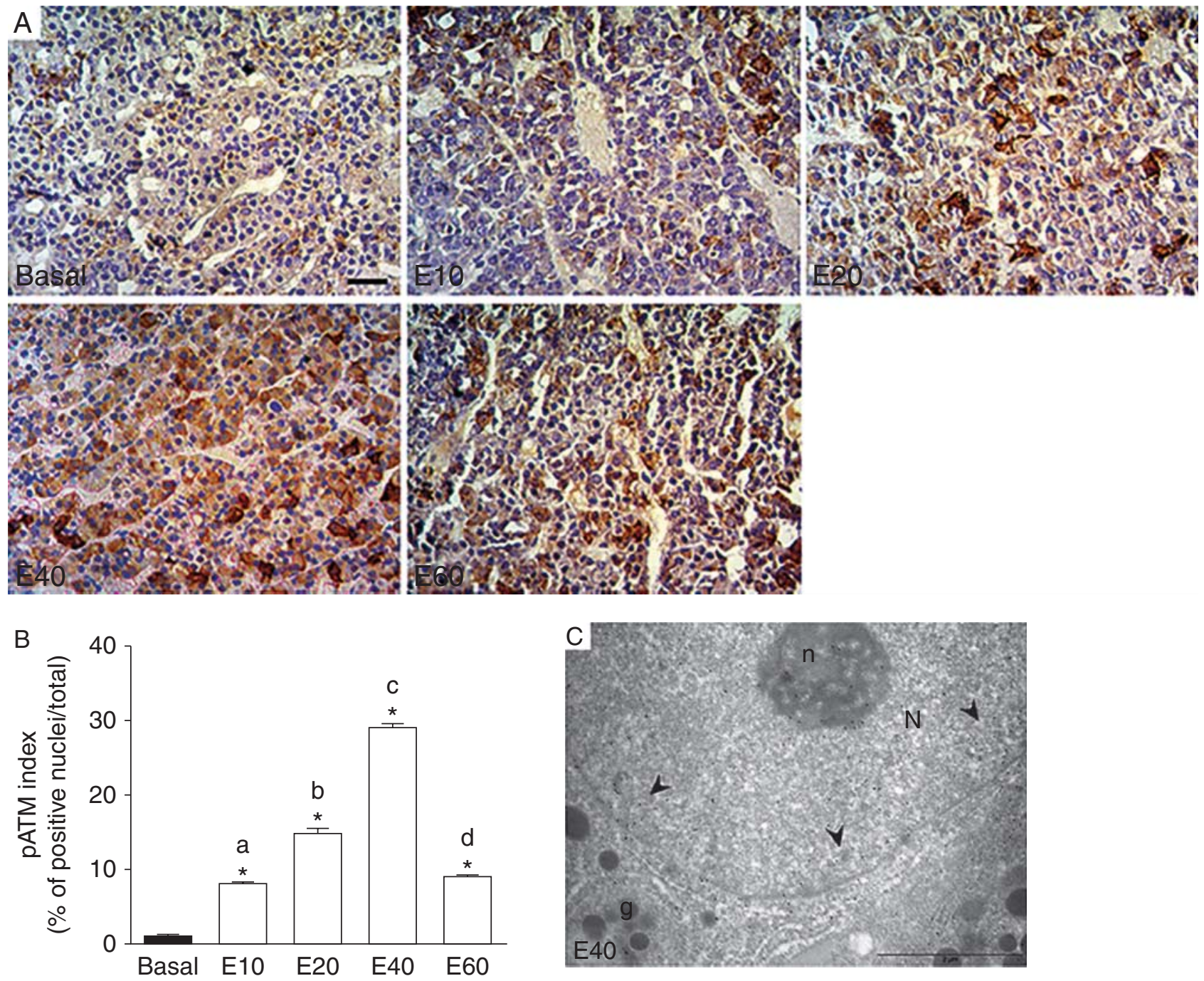

Figure 7

DNA damage in estrogen-induced pituitary tumors. (A) DNA damage signaling labeled by intranuclear accumulation for pATM immunoreactivity (brown signal) in normal and tumoral pituitaries. Representative sections from normal and estrogen-treated anterior pituitary glands are shown. Scale bar $=20 \mu \mathrm{m}$. (B) The PATM-positive nuclei as a proportion of the total nuclei in pituitary sections are shown and results are expressed as means \pm S.E.M.; Fisher's test $\left({ }^{*} P<0.05\right.$ vs basal; means with different letters are

in p53 nuclear fraction levels starting at E20 was also observed (Fig. 8B). Therefore, we next evaluated the expression of the CDK inhibitor $\mathrm{p} 21$ protein, a transcriptional target for $\mathrm{p} 53$ that is involved in cell cycle responses to DNA damage (Besson et al. 2008). By western blotting analysis, an increase in the nuclear p21 was observed, starting from E20 and strengthened over time from 40 to 60 days of tumor development (Fig. 9A). The subcellular localization of p21 analyzed by electron microscopy immunogold labeling for E40 pituitary glands revealed a streaking immunoreactivity in the nuclear and Printed in Great Britain statistically different). (C) Electron micrograph of pituitary cells from E40 expressing pATM label by using secondary antibody conjugated with $15 \mathrm{~nm}$ gold particles. Black arrows indicate PATM signaling accumulated in the cell compartments. $\mathrm{N}$, nucleus; $\mathrm{g}$, hormone granules; $\mathrm{m}$, mitochondrion. Scale bar $=2 \mu \mathrm{m}$. A full colour version of this figure is available at http://dx.doi.org/10.1530/ERC-14-0333.

cytoplasmic compartments of pituitary cells (Fig. 9B), a result that might be related to the lower pituitary cell proliferation detected at E40 (Fig. 2A and B). Moreover, p21 cytoplasmic accumulation was also observed for E20 and E40. However, an additional evaluation performed on GH3B6 tumoral pituitary cells showed that these cells did not express p21 (Fig. 9C), which could be associated with the low SA-b-gal reactivity observed in this cell type (Fig. 4B and C).

Alterations in the pituitary cell cycle profile were analyzed by FACS, and in order to try to discriminate

Published by Bioscientifica Ltd 

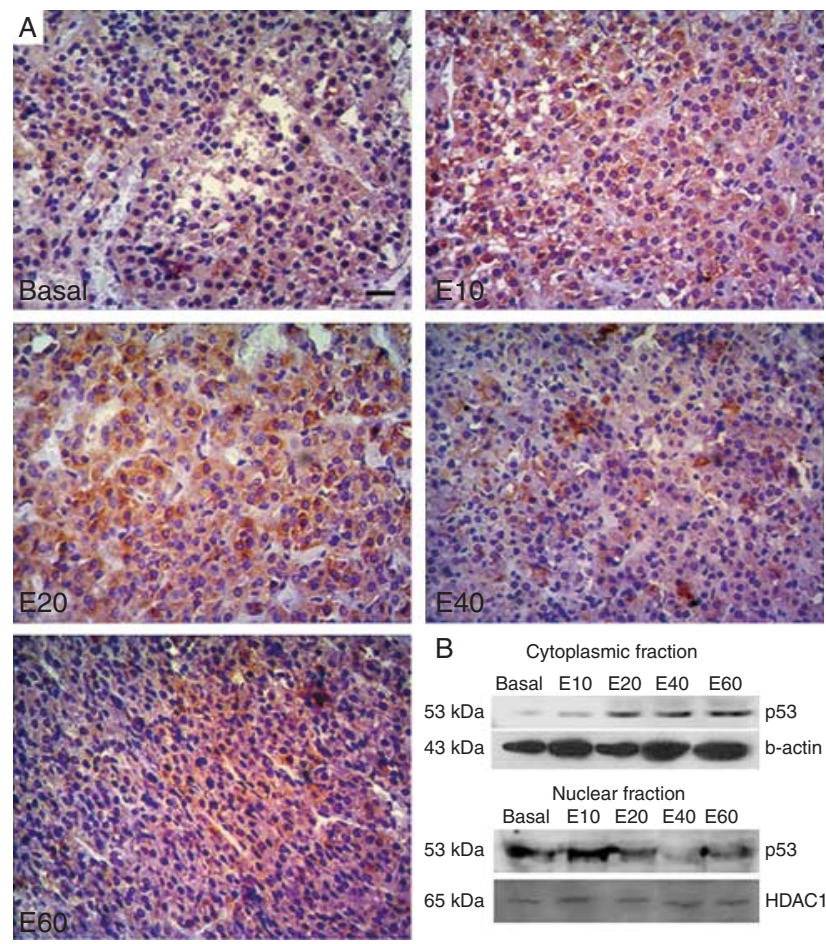

\section{Figure 8}

p53 expression during pituitary tumor development. (A) p53 immunoreactivity (brown signal) in normal and tumoral pituitary sections. An increase in p53 detection is observed at E10 and E20. Representative fields of anterior pituitary sections are also shown. Scale bar $=20 \mu \mathrm{m}$. (B) The p53 expression showed a cytoplasmic redistribution during the tumor development as revealed by western blotting in fractionated pituitary extracts. Expression of b-actin and HDAC1 was used as loading controls. Representative images of three independent experiments are presented. A full colour version of this figure is available at http://dx.doi.org/10.1530/ ERC-14-0333.

between the cycling population and S-phase arrest, the S-phase was compared with the G2/M population, with the result being expressed as a ratio. As shown in Fig. 9D, a significant increase in the S-phase:G2/M ratio was detected for E40 compared with the control ratio $(57.63 \pm 14.87$ vs $12.59 \pm 10.86$ respectively; $P<0.05)$. These results together with the DDR activation and p21 upregulation reinforce the possibility of a delay occurring in the cell cycle progression, which became more evident toward 40 days of tumor progression.

\section{Senescence markers are not restricted to PRL cells}

As most pituitary tumors induced by estrogen in experimental animals are PRL-secreting tumors (De Nicola et al. 1978, Wiklund et al. 1981, Sadoul et al. 1992, Mukdsi et al. 2004), we attempted to determine whether lactotroph specific cell lineage was involved in the pituitary senescent response. The colocalization between PRL/Ki67, PRL/p21, PRL/p53, PRL/pATM, and PRL/Sa-b-gal proteins was carried out by dual immunolabeling for different experimental conditions. As shown in Fig. 10, for all the combination of markers analyzed, it was possible to detect double-stained cells, indicative of lactotrophs, which might possibly be senescent as shown by SA-b-gal, DDR activation by pATM or p21 accumulation indicating cellular arrest. However, along with double-stained cells, it was also possible to observe single-stained cells, representative of either nonsenescent lactotrophs or nonlactotroph cells undergoing senescence. Therefore, none of the marker expressions examined exclusively colocalized with PRL-positive cells, suggesting that the senescence phenomena may not be restricted to lactotroph populations.

\section{Discussion}

In this study, we have demonstrated clear evidence of pituitary senescence taking place during in vivo estrogeninduced pituitary tumor development. The cell proliferation reduction and expression of cellular senescence features such as SA-b-gal and IL6 expression, as well as DNA damage signaling activation and p21 expression, indicate a role for senescence in the regulation of pituitary cell growth.

The particularities of benign pituitary tumors have led to the appearance of senescence being considered, which has been proposed as an intrinsic barrier for tumor development that emerges at the early stages of neoplastic growth (Prieur \& Peeper 2008). This pituitary cellular response might be beneficial for organisms, because it allows proliferation to be arrested while maintaining its physiological functions (Adams 2009), and therefore, hormones may continue to be secreted (Mooi 2009).

The tumor suppression role of cellular senescence has been convincingly established in vitro (Bringold \& Serrano 2000, Campisi 2001, Mooi \& Peeper 2006), but further evidence is still needed to demonstrate the relationship between in vivo senescence and proliferation control (Mooi \& Peeper 2006, Collado \& Serrano 2010). In this context, benign pituitary microadenomas are faithful models of in vivo senescence (Mooi 2009, Chesnokova \& Melmed 2010). Previous studies have already reported that murine pituitary adenomas with altered PTTG and Rb expression trigger cellular senescence (Chesnokova et al. 2007, 2008). These authors also correlated the high levels of growth hormone (GH) with the senescence-associated markers in adenomas, and suggested that cellular senescence is activated in a lineage-specific fashion

Published by Bioscientifica Ltd 
A

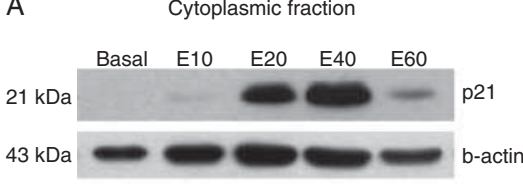

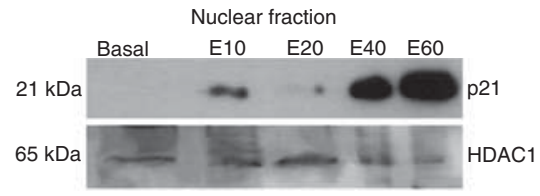

C

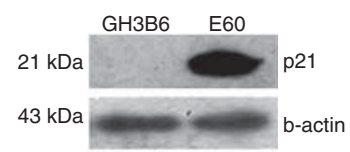

B
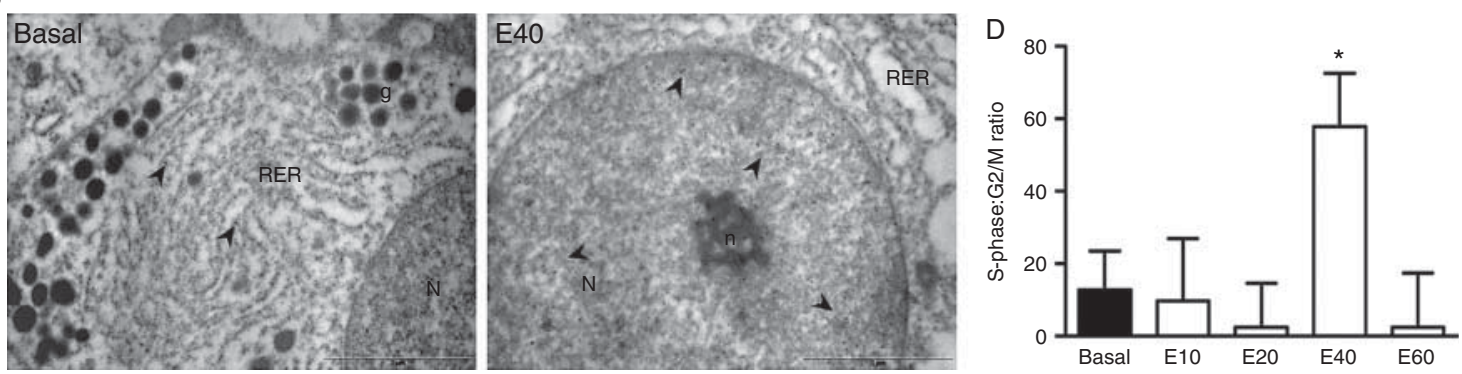

\section{Figure 9}

The expression of CDK inhibitor p21 was increased in tumoral pituitary glands. (A) The analysis of the p21 protein expression levels by western blotting revealed an increase in its expression in both nuclear and cytosolic extracts during tumor development. (B) The ultrastructural localization of p21 was examined in control (basal) and E40 pituitary glands by electron microscopy immunogold labeling. Black arrows indicate p21 signaling mainly expressed at the nuclear cell compartment. N, nucleus; $n$, nucleolus; RER, rough endoplasmic reticulum. Scale bar $=2 \mu \mathrm{m}$. (C) Total extract of established GH3B6 tumoral cells did not express p21. The expression of

(Chesnokova et al. 2008, 2011, 2013). However, to date, no attempt has been made to analyze the emergence of cellular senescence with pituitary tumor progression in the absence of genetic manipulation or specific senescence-inducing stimuli. In this study, we have demonstrated that both senescence markers and DNA damage signaling were expressed during the development of estrogen-induced pituitary tumors. This present in vivo approach allows us to suggest a role of cellular senescence as a pituitary intrinsic response to chronic cellular over-activation.

Although the pituitary cells of adult rats are characterized by low proliferation rates (0.7-0.8\%; McNicol \& Carbajo-Perez 1999), we have observed a strong stimulation of cell proliferation accompanied by hypertrophy and vascular network development after the start of estrogen treatment, with all of these parameters contributing to the significant mass increase revealed by assessing the wet pituitary weight data. Although the proliferation index still presents significantly higher values at E60 than those detected in controls, the initial increase in cell proliferation lost potency at advanced endpoints, indicating a plateau phase in the cell proliferation rate until the end of stimulation, as shown by Ki67 immunoreactivity. Consequently, this biphasic pattern might be distinct from the exponential proliferation b-actin and HDAC1 was used as loading controls. Representative images of three independent experiments are shown. (D) S-phase:G2/M ratio analysis during experimental pituitary tumor development. The DNA content was determined by flow cytometry in order to evaluate modifications in the pituitary cell cycle profile of normal and tumoral pituitary cells. A notable increase in the S-phase:G2/M ratio is observed for E40, when compared with control ratio. The means \pm s.E.M. of the percentages of cells at different cell cycle stages are presented Fisher's test ( ${ }^{*} P<0.05$ vs basal).

typically associated with aggressive tumoral progression (Hanahan \& Weinberg 2000).

Furthermore, GH3B6 represents an equivalent for estrogen-induced pituitary tumor cells, but as an established and autonomous pituitary tumoral stage, showing a basal proliferation rate of around $25-30 \%$ of total cells (Giles et al. 2010, Petiti et al. 2015), while normal pituitary cells showed $1 \%$ of proliferation, with the replication index of estrogen-induced pituitary tumoral cells reaching a maximum of $8 \%$. The use of this tumoral cell line permitted us to analyze the presence of cellular senescence in a cell population, which might represent a clone in the heterotypic tumor complexity that has acquired growth signaling autonomy and may have possibly lost the ability to respond to some cellular arrest signals.

Although intrinsic tumoral suppression has been classically associated with apoptosis induction (Lowe et al. 2004), we detected very few apoptosis events throughout the adenoma development, in agreement with previous findings (Spady et al. 1999, Palmeri et al. 2009). Earlier reports have demonstrated that estrogen administration enhances cell survival in the anterior pituitary gland by inhibiting apoptosis (Spady et al. 1999). Therefore, an apoptotic block manifested during an estrogen-induced tumor development may support

Published by Bioscientifica Ltd. 
Basal
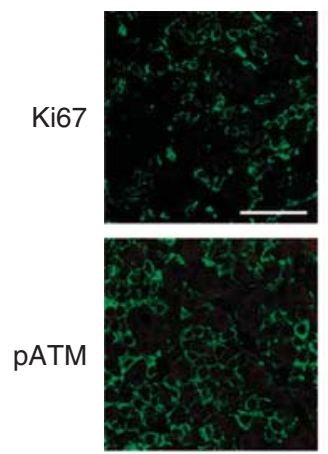

p53

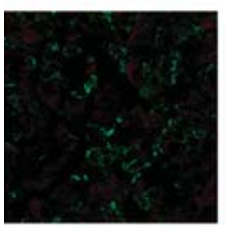

p21

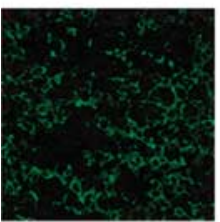

SA-b-gal

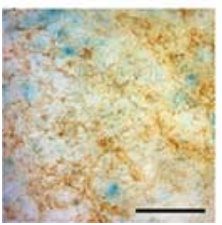

E10
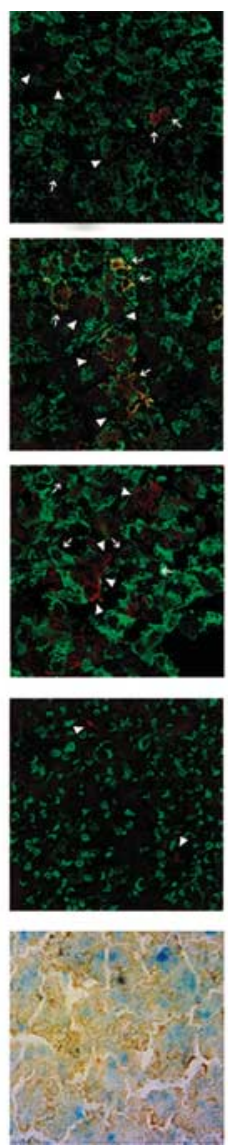

$\mathrm{E} 40$
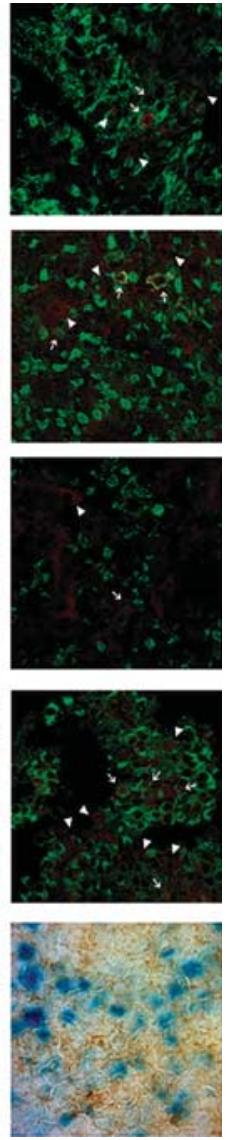

\section{Figure 10}

KI67, pATM, p21, p53, and SA-b-gal expression in lactotroph cells. Confocal laser scanning microscopy of pituitary paraffin-embedded sections from control, E10, and E40 glands co-stained for PRL (green) with Ki67, PATM, p21, or p53 (red). Single-stained lactotrophs, single-stained non-PRL cells (arrowheads), and double-stained lactotrophs (arrows) are seen. Also, immunolabeling for PRL (brown) and histoenzimology for SA-b-gal (blue) were performed on the same cryosection. Data are from a representative experiment from a total of three independent experiments with similar results. Scale bar $=20 \mu \mathrm{m}$. A full colour version of this figure is available at http://dx.doi.org/10.1530/ERC-14-0333.

pituitary senescence being a cytological stress response (Marcotte et al. 2004). In this way, senescence might be a more appropriate mechanism for pituitary tumor suppression, taking into account that the pituitary gland is critical for the homeostatic function, but which exhibits a regenerative capacity (Chesnokova et al. 2013).

It is known that multiple processes might take place in the gland during tumor development. In fact, it is the balance between proliferation with death or senescence that determines the growth rate of a particular tumor (Lowe et al. 2004). The determination of double SA-b-gal-/ Ki67-positive cells allowed us to confirm the idea that senescence is an important outcome in estrogen-induced pituitary tumors, as it was observed to be profuse regarding cell proliferation. In addition, the nonoverlapped distribution of Ki67 and SA-b-gal-positive cells observed at E60 supported the hypothesis of heterotypic cell populations that coexist during tumor development. Hence, it is possible to associate this coexistence of different kinds of responses to the fact that the five cell types constitute the pituitary cell population. Thus, specific diverse cell-type trophic pathways may be activated in reaction to longterm estrogen treatment.

Considering that the senescent cell phenotype still lacks specific markers, in this study several senescenceassociated features were evaluated in order to investigate this cellular mechanism. The strong association between the SASP pattern and the other senescence biomarkers (p21, pATM, and Sa-b-gal) led us to connect these increased cytokine expressions with emerging pituitary senescence within estrogen-induced pituitary tumors. A putative role for IL6 in pituitary senescence induction has been previously suggested (Fuertes et al. 2010), with TGFb1 and IL1b also having a known impact on pituitary tissue homeostasis (Haedo et al. 2009). We have recently demonstrated somatolactotroph GH3B6 tumoral cells exhibiting a refractory behavior to the TGFb1 inhibitory effects on cell cycle progression, as a consequence of the crosstalk with proliferative pathways that counterbalances the TGFb1 signal (Petiti et al. 2015). Considering the specific activities implied in the secretion of each cytokine, while IL6 is considered to be a critical controller of the SASP and seems to have a more significant role in autocrine senescence (Kuilman et al. 2008), the TGFb1 and IL1 as SASP factors are able to trigger senescence by paracrine actions (Hubackova et al. 2012).

In this regard, it is known that the proteins encoded by NFkB target genes contribute in multiple ways to the biological effects of NFkB, which include inflammation response, apoptosis, mitogenic activity, implications in the evolution of neoplastic injuries, cellular senescence, and DNA repair (Hayden \& Ghosh 2004, Pikarsky \& Ben-Neriah 2006). Furthermore, NFkB operates as a molecular switch that conveys signals from an intricate signaling network, thereby regulating essential processes through the gene transcription regulation.

Regarding the focus of our study, NFkB cooperates through feedback regulation within the senescence process, because it can trigger SASP in response to persistent DNA damage signaling (Freund et al. 2010). Therefore, we focused on NFkB activity as an accompaniment of the SASP activation evidence, rather than the association with growth regulation pathways in which NFkB activity may

Published by Bioscientifica Ltd 
also surely participate (Freund et al. 2010). In this context, several reports have implied that SASP induction is an NFkB-dependent mechanism (Acosta et al. 2008, Chien et al. 2011, Salminen et al. 2012), suggesting that the SASP is caused primarily by genotoxic stress rather than by proliferative arrest per se (Freund et al. 2010). From our data, the notable increase in SASP component expression with NFkB activation suggests that the inflammatory network was triggered during pituitary tumor development. Under the present experimental context, the expression of these cytokines collectively reinforces the role of SASP in ensuring an efficient growth arrest, as was also proposed by others (Yang et al. 2006, Acosta et al. 2008, Kuilman et al. 2008, Wajapeyee et al. 2008).

The mitochondrial metabolism is also compromised during cellular senescence, because DNA damage can be powered by oxidative stress triggering premature senescence (Moiseeva et al. 2009). In our study, we detected a decreased DRP1 together with increased MFN1 expression, suggestive of a misbalance between mitochondrial fission toward fusion processes in favor of an enlargement of the organelle. Therefore, the alteration of the mitochondrial dynamics equilibrium toward the prevalence of fusion processes might indicate an adaptation of the functionality of this organelle during pituitary tumor development, occurring together with cellular senescence. Regarding this, an ineffective mitochondrial fission triggering cellular senescence has been previously described (Lee et al. 2007).

In view of the fact that our experimental conditions did not include cytotoxic drugs, irradiation stimuli, or other stimuli strongly associated with DNA damage or senescence induction, the manifestation of senescence signs during the development of the pituitary tumor constitutes a noteworthy finding of our study. Nevertheless, it cannot be ignored that a multiplicity of molecular pathways could be involved in the development of estrogen-induced pituitary tumors (Sarkar 2006). Regarding this, we analyzed RAS/ERK pathway activation due to the fact that abnormally high mitogenic signals such as estrogen-induced RAS activation (Weigel 1996) might function as a prolonged cellular overactivation capable of inducing cellular senescence (Serrano \& Blasco 2001). However, this key core element is part of a complex signaling network with many interactions (McKay \& Morrison 2007), and there have been extensive attempts to clarify its contribution in the promotion of cell growth, with it being the fine regulation of these pathways which determines cell cycle arrest or malignant transformation (Serrano et al. 1997, Roberts \& Der 2007). Moreover, although there are some studies showing increases in RAS/ERK activity in pituitary tumors (Karga et al. 1992, Cai et al. 1994, Dworakowska et al. 2009), its role in these tumors is far from being fully deciphered (Cakir \& Grossman 2009). In our study, RAS/pERK signaling was progressively suppressed thereafter, with its expression being less evident at E40-E60 than at baseline conditions. These results imply that RAS/ERK effects were therefore, to a major extent, impaired, and that there might exist a regulation mechanism that could attenuate the abnormal mitogenic signals. Supporting this notion, Courtois-Cox et al. (2006) have shown that the suppression of RAS is sufficient to induce cellular senescence, and that this event, on its own, can activate the known downstream mediators of the senescence response through a variety of mechanisms.

The detection of PATM expression demonstrated in our study suggests the possibility of DNA damage during experimental tumoral development, because ATM has been reported to be one of the first proteins that responds to DDR (Di Micco et al. 2006). Therefore, the combination of a very high mitogenic signaling, the possibility of chromatin disorder, and a blockage of apoptosis might favor the emergence of cellular senescence as an alternative to control pituitary growth (Di Micco et al. 2006, Chesnokova \& Melmed 2010).

As senescence pathway involves cell cycle machinery committed to cellular arrest (Kuilman et al. 2010), we evaluated pituitary cellular arrest through the analysis of the p53 and p21 restriction-point cell cycle proteins and the cell cycle profile.

It is known that p53 integrates complex signaling networks, increasing lifespan through genome maintenance and triggering various cell fate decisions (Rodier $e t a l$. 2007). At the early stages of pituitary tumor development, we observed an increase in p53 expression levels, with its intracellular localization being principally detected in the cytoplasm compartment. Furthermore, as it has been described that estrogen induces p53 inactivation through intracellular redistribution toward the cytosol (Molinari et al. 2000), our findings could be interpreted as a p53 stabilization mechanism, as previously suggested (Liu et al. 2006). Despite having found DDR activation, the cytoplasmic p53 retention might indicate its incapability to exert its canonical functions, thereby triggering a response that either repairs DNA damage or else removes the affected cell from the replicative pool. This indirect evidence may explain the great accumulation of pATM signaling, thus in turn favoring the increase in the senescence signs observed at E40.

Although in most cells, p53 is crucial for a senescence response following DNA damage (Di Leonardo et al. 1994),

Published by Bioscientifica Ltd 
in others it is only required to induce senescence growth arrest and not necessary for the maintenance of senescence, which subsequently becomes irreversible and p53 independent (Beausejour et al. 2003). Thus, cellular senescence might not appear to entail a consistent sustained rise in p53 protein levels (Itahana et al. 2001). Under our experimental conditions, it is possible that nuclear p53 initiated both senescence growth arrest and some of the functional aspects of the senescent phenotype by inducing $\mathrm{p} 21$. These $\mathrm{p} 21$ levels can then be sustained, at least for several weeks, by a p53-independent mechanism (Itahana et al. 2001).

CDK inhibitor p21 expression, strongly related to cellular senescence pathways, elicits cell cycle arrest (Roninson 2002). Pituitary growth control by p21 has already been described, indicating its key role in senescence pathways, while it was undetectable in pituitary carcinomas (Chesnokova et al. 2007). In this study, the upregulation of nuclear $\mathrm{p} 21$ protein expression in close relationship with the highest levels of SA-b-gal reactivity suggests that cell cycle restraint might take place during the development of pituitary tumors. Moreover, in our study, the lack of SA-b-gal and p21 protein expression reactivity in GH3B6 pituitary cells indicates the incapability of these cells to trigger a self-limiting senescence arrest at the tumoral stage acquired in GH3B6 cells. In fact, Chesnokova et al. (2008) have already reported that p21 expression underlies decreased pituitary tumor development, and that this CDK inhibitor was undetectable in tested human pituitary carcinomas. Thus, under the present experimental conditions, p21 might constitute another significant mediator in constraining pituitary growth in tumor development. In addition, it has been reported that this CDK inhibitor can function under either p53-dependent or independent conditions (Gartel \& Tyner 1999). Considering that in our study no association between the increase in p21 levels with a p53 expression pattern was seen, p21 might therefore be induced in a p53independent fashion. In agreement with this, p53independent effects of p21 have also been reported in relationship with cell cycle arrest of senescent cells (Noda et al. 1994). Furthermore, some studies have presented evidence of induction of the CDK inhibitor p21 in response to activation of the cytokines IL6 and TGFb signal transduction pathways (Zeng \& el-Deiry 1996, Bellido et al. 1998, Florenes et al. 1999). Thus, SASP induction in experimental pituitary tumors may be responsible for senescence cell growth arrest through p21 induction. Concerning the increase observed in cytoplasmic p21, this data could be interpreted as the outcome of the increased p21 synthesis or a degradation taking place in the cytoplasm. Nonetheless, it may also be linked to apoptosis delay or inhibition due to pleitropic context-dependent p21 functions (Arai et al. 2006).

The CDK inhibitor p21 is also responsible for inhibiting ongoing DNA synthesis, thus allowing time for DNA repair (Luo et al. 1995), and also playing a role in the G2 phase transition (Besson et al. 2008). The significant decrease in the G2/M cell proportion observed at E40, concomitant with an increase in p21 expression and DDR activation, may indicate a p21-mediated blockage of ongoing DNA synthesis, which was involved, at least in part, in the declining cell progression from the $S$ phase to $\mathrm{G} 2 / \mathrm{M}$. Considering that S-phase checkpoint activation in response to DNA damage has been previously reported (Ogryzko et al. 1997, Pedeux et al. 1998, Knudsen et al. 2000), our results suggest a possible delay taking place in the cell cycle progression mediated by $\mathrm{p} 21$, provoked by the occurrence of high DDR signaling.

Considering that prolactinomas are the most frequently occurring neoplasms in humans and in laboratory animals (Ciccarelli et al. 2005), we found that during estrogeninduced pituitary tumor growth, the expression of all the senescence markers used was not confined to the lactotroph population. The direct assumption of the involvement of PRL cells in pituitary senescence may be premature for several reasons. Firstly, alpha and beta estrogen receptors are also present in folliculostellate (Mitchner et al. 1998), somatotroph, thyrotroph, and gonadotroph cells (Nishihara et al. 2000, Gonzalez et al. 2008). Also, compelling reports by Nolan \& Levy (2009) in Wistar male rats have shown that approximately two-thirds of anterior pituitary cell divisions after estrogen treatment occur in non-PRLpositive cells, with only one-thirds of the mitotic figures corresponding to lactotroph cells.

PRL cells might represent a phenotype less sensitive to growth inhibition programs. Indeed, other reports have suggested that the senescence contribution to benign pituitary tumor development might be cell-type specific rather than universal. In agreement, Chesnokova et al. (2008) have described senescence taking place predominantly in GH-secreting tumors, and to a lesser extent in PRL-secreting tumors. In addition, Alexandraki et al. (2012) showed that SA-b-gal is overexpressed only in nonfunctional pituitary adenomas and GH-secreting tumors, and that in the context of senescence, these adenomas behave differently compared with ACTH- and PRL-secreting adenomas. Finally, as the great majority of pituitary carcinomas are derived from these latter types of adenoma, we might speculate that the lack or bypass of

Published by Bioscientifica Ltd. 
senescence in lactotrophs may permit the occasional prolactinoma to develop into a carcinoma. In this study, we have provided evidence for the involvement of senescence from the early proliferative response of the pituitary gland to estrogen and also we have demonstrated that the changes observed were not associated exclusively with PRL cells.

In summary, in this study, we have demonstrated clear evidence of the emergence of pituitary senescence in the development of tumoral pituitary injuries induced by estrogen. The association between DDR activation, SA-bgal expression, and p21 involvement constitutes a reliable combination of senescence-associated markers for in vivo pituitary senescence detection. Moreover, the participation of cellular senescence should be conceived as a contributing component behind the strikingly benign intrinsic nature of pituitary adenomas, thereby influencing the capability of the pituitary gland to avoid unregulated cell proliferation. Understanding this mechanism might provide significant insights into cancer control networks and lead to new therapeutic strategies. The future recognition of the intracellular targets involved in the responses to anti-mitogenic signals would also help to interpret the abnormalities responsible for their dysfunction in tumorigenesis.

\section{Declaration of interest}

The authors declare that there is no conflict of interest that could be perceived as prejudicing the impartiality of the research reported.

\section{Funding}

This work was supported by the Fondo Nacional de Ciencia y Tecnología (FONCYT), Consejo Nacional de Investigaciones Científicas y Técnicas (CONICET), and Secretaría de Ciencia y Tecnología de la Universidad Nacional de Córdoba (SECyT-UNC). M E Sabatino and PA Pérez are doctoral fellows at the Consejo Nacional de Investigaciones Científicas y Técnicas. $\mathrm{L} d \mathrm{~V}$ Sosa and C Leimgruber are postdoctoral fellows at Consejo Nacional de Investigaciones Científicas y Técnicas. J P Petiti, S Gutiérrez, A I Torres and A L De Paul are established researchers at the Centro de Microscopía Electrónica, Instituto de Investigaciones en Ciencias de la Salud, Consejo Nacional de Investigaciones Científicas y Técnicas (INICSA-CONICET), Facultad de Ciencias Médicas, Universidad Nacional de Córdoba. A Latini is established researcher at the Conselho Nacional de Desenvolvimento Científico e Tecnológico (CNPq), Laboratorio de Bioenergética y Estrés Oxidativo, Departamento de Bioquímica, Centro de Ciencias Biológicas, Universidad Federal de Santa Catarina, Brazil.

\section{Acknowledgements}

The authors wish to thank Ms Elena Pereyra and Ms Lucía Artino for their excellent technical assistance. They would also like to thank native speaker Dr Paul Hobson for revising the English of the manuscript.

\section{References}

Acosta JC, O'Loghlen A, Banito A, Guijarro MV, Augert A, Raguz S, Fumagalli M, Da Costa M, Brown C, Popov N et al. 2008 Chemokine signaling via the CXCR2 receptor reinforces senescence. Cell 133 1006-1018. (doi:10.1016/j.cell.2008.03.038)

Adams PD 2009 Healing and hurting: molecular mechanisms, functions, and pathologies of cellular senescence. Molecular Cell 36 2-14. (doi:10.1016/j.molcel.2009.09.021)

Alexandraki KI, Munayem Khan M, Chahal HS, Dalantaeva NS, Trivellin G, Berney DM, Caron P, Popovic V, Pfeifer M, Jordan S et al. 2012 Oncogene-induced senescence in pituitary adenomas and carcinomas. Hormones 11 297-307. (doi:10.14310/horm.2002.1358)

Arai D, Nomura N, Fukuchi K \& Gomi K 2006 Cytoplasmic localization of cyclin kinase inhibitor p21 delays the progression of apoptosis. Cancer Genomics \& Proteomics 310.

Asa SL \& Ezzat S 2002 The pathogenesis of pituitary tumours. Nature Reviews. Cancer 2 836-849. (doi:10.1038/nrc926)

Asa SL \& Ezzat S 2009 The pathogenesis of pituitary tumors. Annual Review of Pathology 4 97-126. (doi:10.1146/annurev.pathol.4.110807.092259)

Baschong W, Suetterlin R \& Laeng RH 2001 Control of autofluorescence of archival formaldehyde-fixed, paraffin-embedded tissue in confocal laser scanning microscopy (CLSM). Journal of Histochemistry and Cytochemistry 49 1565-1572. (doi:10.1177/002215540104901210)

Beausejour CM, Krtolica A, Galimi F, Narita M, Lowe SW, Yaswen P \& Campisi J 2003 Reversal of human cellular senescence: roles of the p53 and p16 pathways. EMBO Journal 22 4212-4222. (doi:10.1093/emboj/ $\operatorname{cdg} 417)$

Bellido T, O'Brien CA, Roberson PK \& Manolagas SC 1998 Transcriptional activation of the p21(WAF1,CIP1,SDI) gene by interleukin-6 type cytokines. A prerequisite for their pro-differentiating and antiapoptotic effects on human osteoblastic cells. Journal of Biological Chemistry 273 21137-21144. (doi:10.1074/jbc.273.33.21137)

Besson A, Dowdy SF \& Roberts JM 2008 CDK inhibitors: cell cycle regulators and beyond. Developmental Cell 14 159-169. (doi:10.1016/j.devcel. 2008.01.013)

Braig M, Lee S, Loddenkemper C, Rudolph C, Peters AH, Schlegelberger B, Stein H, Dorken B, Jenuwein T \& Schmitt CA 2005 Oncogene-induced senescence as an initial barrier in lymphoma development. Nature $\mathbf{4 3 6}$ 660-665. (doi:10.1038/nature03841)

Bringold F \& Serrano M 2000 Tumor suppressors and oncogenes in cellular senescence. Experimental Gerontology 35 317-329. (doi:10.1016/S05315565(00)00083-8)

Cai WY, Alexander JM, Hedley-Whyte ET, Scheithauer BW, Jameson JL, Zervas NT \& Klibanski A 1994 ras mutations in human prolactinomas and pituitary carcinomas. Journal of Clinical Endocrinology and Metabolism 78 89-93. (doi:10.1210/jcem.78.1.8288721)

Cakir M \& Grossman AB 2009 Targeting MAPK (Ras/ERK) and PI3K/Akt pathways in pituitary tumorigenesis. Expert Opinion on Therapeutic Targets 13 1121-1134. (doi:10.1517/14728220903170675)

Campisi J 2001 Cellular senescence as a tumor-suppressor mechanism. Trends in Cell Biology 11 S27-S31. (doi:10.1016/S0962-8924(01) 82148-6)

Campisi J 2005 Suppressing cancer: the importance of being senescent. Science 309 886-887. (doi:10.1126/science.1116801)

Campisi J \& d'Adda di Fagagna F 2007 Cellular senescence: when bad things happen to good cells. Nature Reviews. Molecular Cell Biology $\mathbf{8}$ 729-740. (doi:10.1038/nrm2233)

Chen Z, Trotman LC, Shaffer D, Lin HK, Dotan ZA, Niki M, Koutcher JA, Scher HI, Ludwig T, Gerald W et al. 2005 Crucial role of p53-dependent cellular senescence in suppression of Pten-deficient tumorigenesis. Nature 436 725-730. (doi:10.1038/nature03918)

Chesnokova V \& Melmed S 2010 Pituitary senescence: the evolving role of Pttg. Molecular and Cellular Endocrinology 326 55-59. (doi:10.1016/ j.mce.2010.02.012)

Published by Bioscientifica Ltd. 
Chesnokova V, Zonis S, Rubinek T, Yu R, Ben-Shlomo A, Kovacs K, Wawrowsky K \& Melmed S 2007 Senescence mediates pituitary hypoplasia and restrains pituitary tumor growth. Cancer Research 67 10564-10572. (doi:10.1158/0008-5472.CAN-07-0974)

Chesnokova V, Zonis S, Kovacs K, Ben-Shlomo A, Wawrowsky K, Bannykh S \& Melmed S 2008 p21(Cip1) restrains pituitary tumor growth. PNAS 105 17498-17503. (doi:10.1073/pnas.0804810105)

Chesnokova V, Zonis S, Zhou C, Ben-Shlomo A, Wawrowsky K, Toledano Y, Tong Y, Kovacs K, Scheithauer B \& Melmed S 2011 Lineage-specific restraint of pituitary gonadotroph cell adenoma growth. PLOS ONE 6 e17924. (doi:10.1371/journal.pone.0017924)

Chesnokova V, Zhou C, Ben-Shlomo A, Zonis S, Tani Y, Ren SG \& Melmed S 2013 Growth hormone is a cellular senescence target in pituitary and nonpituitary cells. PNAS 110 E3331-E3339. (doi:10.1073/pnas. 1310589110)

Chien Y, Scuoppo C, Wang X, Fang X, Balgley B, Bolden JE, Premsrirut P, Luo W, Chicas A, Lee CS et al. 2011 Control of the senescenceassociated secretory phenotype by NF- $\kappa \mathrm{B}$ promotes senescence and enhances chemosensitivity. Genes and Development 25 2125-2136. (doi:10.1101/gad.17276711)

Ciccarelli A, Daly AF \& Beckers A 2005 The epidemiology of prolactinomas. Pituitary 8 3-6. (doi:10.1007/s11102-005-5079-0)

Collado M \& Serrano M 2010 Senescence in tumours: evidence from mice and humans. Nature Reviews. Cancer 10 51-57. (doi:10.1038/nrc2772)

Collado M, Gil J, Efeyan A, Guerra C, Schuhmacher AJ, Barradas M, Benguria A, Zaballos A, Flores JM, Barbacid M et al. 2005 Tumour biology: senescence in premalignant tumours. Nature 436642. (doi:10.1038/436642a)

Coppe JP, Patil CK, Rodier F, Sun Y, Munoz DP, Goldstein J, Nelson PS, Desprez PY \& Campisi J 2008 Senescence-associated secretory phenotypes reveal cell-nonautonomous functions of oncogenic RAS and the p53 tumor suppressor. PLoS Biology 6 2853-2868. (doi:10.1371/journal. pbio.0060301)

Courtois-Cox S, Genther Williams SM, Reczek EE, Johnson BW McGillicuddy LT, Johannessen CM, Hollstein PE, MacCollin M \& Cichowski K 2006 A negative feedback signaling network underlies oncogene-induced senescence. Cancer Cell 10 459-472. (doi:10.1016/ j.ccr.2006.10.003)

De Nicola AF, von Lawzewitsch I, Kaplan SE \& Libertun C 1978 Biochemical and ultrastructural studies on estrogen-induced pituitary tumors in F344 rats. Journal of the National Cancer Institute 61 753-763. (doi:10.1093/jnci/61.3.753)

De Paul A, Pons P, Aoki A \& Torres A 1997 Different behavior of lactotroph cell subpopulations in response to angiotensin II and thyrotrophinreleasing hormone. Cellular and Molecular Neurobiology 17 245-258. (doi:10.1023/A:1026322130243)

De Paul AL, Attademo AM, Caron RW, Soaje M, Torres AI, Jahn GA \& Celis ME 2009 Neuropeptide glutamic-isoleucine (NEI) specifically stimulates the secretory activity of gonadotrophs in primary cultures of female rat pituitary cells. Peptides 30 2081-2087. (doi:10.1016/j. peptides.2009.08.022)

Di Leonardo A, Linke SP, Clarkin K \& Wahl GM 1994 DNA damage triggers a prolonged p53-dependent G1 arrest and long-term induction of Cip1 in normal human fibroblasts. Genes and Development 8 2540-2551. (doi:10.1101/gad.8.21.2540)

Di Micco R, Fumagalli M, Cicalese A, Piccinin S, Gasparini P, Luise C, Schurra C, Garre M, Giovanni Nuciforo P, Bensimon A et al. 2006 Oncogene-induced senescence is a DNA damage response triggered by DNA hyper-replication. Nature 444 638-642. (doi:10.1038/ nature05327)

Dimri GP, Lee X, Basile G, Acosta M, Scott G, Roskelley C, Medrano EE, Linskens M, Rubelj I, Pereira-Smith O et al. 1995 A biomarker that identifies senescent human cells in culture and in aging skin in vivo. PNAS 92 9363-9367. (doi:10.1073/pnas.92.20.9363)

Dworakowska D, Wlodek E, Leontiou CA, Igreja S, Cakir M, Teng M, Prodromou N, Goth MI, Grozinsky-Glasberg S, Gueorguiev M et al.
2009 Activation of RAF/MEK/ERK and PI3K/AKT/mTOR pathways in pituitary adenomas and their effects on downstream effectors. Endocrine-Related Cancer 16 1329-1338. (doi:10.1677/ERC-09-0101)

Florenes VA, Lu C, Bhattacharya N, Rak J, Sheehan C, Slingerland JM \& Kerbel RS 1999 Interleukin-6 dependent induction of the cyclin dependent kinase inhibitor p21WAF1/CIP1 is lost during progression of human malignant melanoma. Oncogene 18 1023-1032. (doi:10.1038/ sj.onc.1202382)

Freund A, Orjalo AV, Desprez PY \& Campisi J 2010 Inflammatory networks during cellular senescence: causes and consequences. Trends in Molecular Medicine 16 238-246. (doi:10.1016/j.molmed.2010.03.003)

Fuertes M, Gerez J, Haedo M, Giacomini D, Paez-Pereda M, Labeur M, Stalla GK \& Arzt E 2010 Cytokines and genes in pituitary tumorigenesis: RSUME role in cell biology. Frontiers of Hormone Research 38 1-6. (doi:10.1159/000318488)

Gartel AL \& Tyner AL 1999 Transcriptional regulation of the p21(WAF1/CIP1) gene. Experimental Cell Research 246 280-289. (doi:10.1006/excr. 1998.4319)

Giles A, Madec F, Friedrichsen S, Featherstone K, Chambers T, Harper CV, Resch J, Brabant G \& Davis JR 2010 Wnt signaling in estrogen-induced lactotroph proliferation. Journal of Cell Science 124 540-547. (doi:10.1242/jcs.078642)

Gonzalez M, Reyes R, Damas C, Alonso R \& Bello AR 2008 Oestrogen receptor $\alpha$ and $\beta$ in female rat pituitary cells: an immunochemical study. General and Comparative Endocrinology 155 857-868. (doi:10.1016/j.ygcen.2007.10.007)

Haedo MR, Gerez J, Fuertes M, Giacomini D, Paez-Pereda M, Labeur M, Renner U, Stalla GK \& Arzt E 2009 Regulation of pituitary function by cytokines. Hormone Research 72 266-274. (doi:10.1159/000245928)

Hanahan D \& Weinberg RA 2000 The hallmarks of cancer. Cell 100 57-70. (doi:10.1016/S0092-8674(00)81683-9)

Hayden MS \& Ghosh S 2004 Signaling to NF-кB. Genes and Development 18 2195-2224. (doi:10.1101/gad.1228704)

Holst CR, Nuovo GJ, Esteller M, Chew K, Baylin SB, Herman JG \& Tlsty TD 2003 Methylation of p16(INK4a) promoters occurs in vivo in histologically normal human mammary epithelia. Cancer Research 63 1596-1601.

Hubackova S, Krejcikova K, Bartek J \& Hodny Z 2012 IL1- and TGF $\beta-N o x 4$ signaling, oxidative stress and DNA damage response are shared features of replicative, oncogene-induced, and drug-induced paracrine 'bystander senescence'. Aging 4 932-951.

Itahana K, Dimri G \& Campisi J 2001 Regulation of cellular senescence by p53. European Journal of Biochemistry 268 2784-2791. (doi:10.1046/ j.1432-1327.2001.02228.x)

Karga HJ, Alexander JM, Hedley-Whyte ET, Klibanski A \& Jameson JL 1992 Ras mutations in human pituitary tumors. Journal of Clinical Endocrinology and Metabolism 74 914-919. (doi:10.1210/jc.74.4.914)

Knudsen KE, Booth D, Naderi S, Sever-Chroneos Z, Fribourg AF, Hunton IC, Feramisco JR, Wang JY \& Knudsen ES 2000 RB-dependent S-phase response to DNA damage. Molecular and Cellular Biology 20 7751-7763. (doi:10.1128/MCB.20.20.7751-7763.2000)

Kuilman T, Michaloglou C, Vredeveld LC, Douma S, van Doorn R, Desmet CJ, Aarden LA, Mooi WJ \& Peeper DS 2008 Oncogene-induced senescence relayed by an interleukin-dependent inflammatory network. Cell $\mathbf{1 3 3}$ 1019-1031. (doi:10.1016/j.cell.2008.03.039)

Kuilman T, Michaloglou C, Mooi WJ \& Peeper DS 2010 The essence of senescence. Genes and Development 24 2463-2479. (doi:10.1101/gad. 1971610)

Lee BY, Han JA, Im JS, Morrone A, Johung K, Goodwin EC, Kleijer WJ, DiMaio D \& Hwang ES 2006 Senescence-associated $\beta$-galactosidase is lysosomal $\beta$-galactosidase. Aging Cell 5 187-195. (doi:10.1111/ j.1474-9726.2006.00199.x)

Lee S, Jeong SY, Lim WC, Kim S, Park YY, Sun X, Youle RJ \& Cho H 2007 Mitochondrial fission and fusion mediators, hFis1 and OPA1, modulate cellular senescence. Journal of Biological Chemistry 282 22977-22983. (doi:10.1074/jbc.M700679200) 
Levy A 2002 Physiological implications of pituitary trophic activity. Journal of Endocrinology 174 147-155. (doi:10.1677/joe.0.1740147)

Liu W, Konduri SD, Bansal S, Nayak BK, Rajasekaran SA, Karuppayil SM, Rajasekaran AK \& Das GM 2006 Estrogen receptor- $\alpha$ binds p53 tumor suppressor protein directly and represses its function. Journal of Biological Chemistry 281 9837-9840. (doi:10.1074/jbc.C600001200)

Lowe SW, Cepero E \& Evan G 2004 Intrinsic tumour suppression. Nature 432 307-315. (doi:10.1038/nature03098)

Luo Y, Hurwitz J \& Massague J 1995 Cell-cycle inhibition by independent CDK and PCNA binding domains in p21Cip1. Nature 375 159-161. (doi:10.1038/375159a0)

Maiza JC \& Caron P 2009 Pituitary carcinomas and aggressive adenomas: an overview and new therapeutic options. Annales d'Endocrinologie 70 (Suppl 1) S12-S19. (doi:10.1016/S0003-4266(09)72471-0)

Marcotte R, Lacelle C \& Wang E 2004 Senescent fibroblasts resist apoptosis by downregulating caspase-3. Mechanisms of Ageing and Development 125 777-783. (doi:10.1016/j.mad.2004.07.007)

McKay MM \& Morrison DK 2007 Integrating signals from RTKs to ERK/MAPK. Oncogene 26 3113-3121. (doi:10.1038/sj.onc.1210394)

McNicol AM \& Carbajo-Perez E 1999 Aspects of anterior pituitary growth, with special reference to corticotrophs. Pituitary $1257-268$. (doi:10.1023/A:1009950308561)

Melmed S 2003 Mechanisms for pituitary tumorigenesis: the plastic pituitary. Journal of Clinical Investigation 112 1603-1618. (doi:10.1172/ JCI20401)

Michaloglou C, Vredeveld LC, Soengas MS, Denoyelle C, Kuilman T, van der Horst CM, Majoor DM, Shay JW, Mooi WJ \& Peeper DS 2005 BRAFE600-associated senescence-like cell cycle arrest of human naevi. Nature 436 720-724. (doi:10.1038/nature03890)

Mitchner NA, Garlick C \& Ben-Jonathan N 1998 Cellular distribution and gene regulation of estrogen receptors $\alpha$ and $\beta$ in the rat pituitary gland. Endocrinology 139 3976-3983. (doi:10.1210/endo.139.9.6181)

Moiseeva O, Bourdeau V, Roux A, Deschenes-Simard X \& Ferbeyre G 2009 Mitochondrial dysfunction contributes to oncogene-induced senescence. Molecular and Cellular Biology 29 4495-4507. (doi:10.1128/МСB. 01868-08)

Molinari AM, Bontempo P, Schiavone EM, Tortora V, Verdicchio MA, Napolitano M, Nola E, Moncharmont B, Medici N, Nigro V et al. 2000 Estradiol induces functional inactivation of p53 by intracellular redistribution. Cancer Research 60 2594-2597.

Mooi WJ 2009 Oncogene-induced cellular senescence: causal factor in the growth arrest of pituitary microadenomas? Hormone Research 71 (Suppl 2) 78-81. (doi:10.1159/000192442)

Mooi WJ \& Peeper DS 2006 Oncogene-induced cell senescence - halting on the road to cancer. New England Journal of Medicine 355 1037-1046. (doi:10.1056/NEJMra062285)

Mukdsi JH, De Paul AL, Munoz S, Aoki A \& Torres AI 2004 Immunolocalization of Pit-1 in gonadotroph nuclei is indicative of the transdifferentiation of gonadotroph to lactotroph cells in prolactinomas induced by estrogen. Histochemistry and Cell Biology 121 453-462. (doi:10.1007/ s00418-004-0661-5)

Mukdsi JH, De Paul AL, Petiti JP, Gutierrez S, Aoki A \& Torres AI 2006 Pattern of FGF-2 isoform expression correlated with its biological action in experimental prolactinomas. Acta Neuropathologica 112 491-501. (doi:10.1007/s00401-006-0101-9)

Nishihara E, Nagayama Y, Inoue S, Hiroi H, Muramatsu M, Yamashita S \& Koji T 2000 Ontogenetic changes in the expression of estrogen receptor $\alpha$ and $\beta$ in rat pituitary gland detected by immunohistochemistry. Endocrinology 141 615-620. (doi:10.1210/endo.141.2.7330)

Noda A, Ning Y, Venable SF, Pereira-Smith OM \& Smith JR 1994 Cloning of senescent cell-derived inhibitors of DNA synthesis using an expression screen. Experimental Cell Research 211 90-98. (doi:10.1006/excr.1994. 1063)

Nolan LA \& Levy A 2009 The trophic effects of oestrogen on male rat anterior pituitary lactotrophs. Journal of Neuroendocrinology 21 457-464. (doi:10.1111/j.1365-2826.2009.01864.x)
Ogryzko VV, Wong P \& Howard BH 1997 WAF1 retards S-phase progression primarily by inhibition of cyclin-dependent kinases. Molecular and Cellular Biology 17 4877-4882.

Palmeri CM, Petiti JP, Sosa Ldel V, Gutierrez S, De Paul AL, Mukdsi JH \& Torres AI 2009 Bromocriptine induces parapoptosis as the main type of cell death responsible for experimental pituitary tumor shrinkage. Toxicology and Applied Pharmacology 240 55-65. (doi:10.1016/j.taap. 2009.07.002)

Pedeux R, Al-Irani N, Marteau C, Pellicier F, Branche R, Ozturk M, Franchi J \& Dore JF 1998 Thymidine dinucleotides induce $S$ phase cell cycle arrest in addition to increased melanogenesis in human melanocytes. Journal of Investigative Dermatology 111 472-477. (doi:10.1046/j.15231747.1998.00324.x)

Petiti JP, Gutierrez S, De Paul AL, Andreoli V, Palmeri CM, Sosa Ldel V, Bocco JL \& Torres AI 2010 GH3B6 pituitary tumor cell proliferation is mediated by PKC $\alpha$ and PKC $\varepsilon$ via ERK 1/2-dependent pathway. Cellular Physiology and Biochemistry 26 135-146. (doi:10.1159/ 000320519)

Petiti JP, Sosa Ldel V, Sabatino ME, Vaca AM, Gutierrez S, De Paul AL \& Torres AI 2015 Involvement of MEK/ERK1/2 and PI3K/Akt pathways in the refractory behavior of GH3B6 pituitary tumor cells to the inhibitory effect of TGF $\beta 1$. Endocrinology 156 534-547. (doi:10.1210/ en.2014-1070)

Pikarsky E \& Ben-Neriah Y 2006 NF-кB inhibition: a double-edged sword in cancer? European Journal of Cancer 42 779-784. (doi:10.1016/j.ejca. 2006.01.011)

Pluquet O \& Hainaut P 2001 Genotoxic and non-genotoxic pathways of p53 induction. Cancer Letters 174 1-15. (doi:10.1016/S0304-3835(01)00698-X)

Prieur A \& Peeper DS 2008 Cellular senescence in vivo: a barrier to tumorigenesis. Current Opinion in Cell Biology 20 150-155. (doi:10.1016/ j.ceb.2008.01.007)

Roberts PJ \& Der CJ 2007 Targeting the Raf-MEK-ERK mitogen-activated protein kinase cascade for the treatment of cancer. Oncogene $\mathbf{2 6}$ 3291-3310. (doi:10.1038/sj.onc.1210422)

Rodier F, Campisi J \& Bhaumik D 2007 Two faces of p53: aging and tumor suppression. Nucleic Acids Research 35 7475-7484. (doi:10.1093/ nar/gkm744)

Roninson IB 2002 Oncogenic functions of tumour suppressor p21(Waf1/Cip1/Sdi1): association with cell senescence and tumourpromoting activities of stromal fibroblasts. Cancer Letters 179 1-14. (doi:10.1016/S0304-3835(01)00847-3)

Sabatino ME, Sosa Ldel V, Petiti JP, Mukdsi JH, Mascanfroni ID, Pellizas CG, Gutierrez S, Torres AI \& De Paul AL 2013 Functional Toll-like receptor 4 expressed in lactotrophs mediates LPS-induced proliferation in experimental pituitary hyperplasia. Experimental Cell Research 319 3020-3034. (doi:10.1016/j.yexcr.2013.08.012)

Sadoul JL, Thyss A \& Freychet P 1992 Invasive mixed growth hormone/ prolactin secreting pituitary tumour: complete shrinking by octreotide and bromocriptine, and lack of tumour growth relapse 20 months after octreotide withdrawal. Acta Endocrinologica 126 179-183. (doi:10.1530/ acta.0.1260179)

Salminen A, Kauppinen A \& Kaarniranta K 2012 Emerging role of NF-кB signaling in the induction of senescence-associated secretory phenotype (SASP). Cellular Signalling 24 835-845. (doi:10.1016/j.cellsig. 2011.12.006)

Sarkar DK 2006 Genesis of prolactinomas: studies using estrogen-treated animals. Frontiers of Hormone Research 35 32-49. (doi:10.1159/ 000094307)

Serrano M \& Blasco MA 2001 Putting the stress on senescence. Current Opinion in Cell Biology 13 748-753. (doi:10.1016/S0955-0674 (00)00278-7)

Serrano M, Lin AW, McCurrach ME, Beach D \& Lowe SW 1997 Oncogenic ras provokes premature cell senescence associated with accumulation of p53 and p16INK4a. Cell 88 593-602. (doi:10.1016/S0092-8674 (00)81902-9) 
Spady TJ, McComb RD \& Shull JD 1999 Estrogen action in the regulation of cell proliferation, cell survival, and tumorigenesis in the rat anterior pituitary gland. Endocrine 11 217-233. (doi:10.1385/ENDO:11:3:217)

Sugawara A, Yen PM, Darling DS \& Chin WW 1993 Characterization and tissue expression of multiple triiodothyronine receptor-auxiliary proteins and their relationship to the retinoid X-receptors. Endocrinology 133 965-971. (doi:10.1210/endo.133.3.8396023)

Wajapeyee N, Serra RW, Zhu X, Mahalingam M \& Green MR 2008 Oncogenic BRAF induces senescence and apoptosis through pathways mediated by the secreted protein IGFBP7. Cell 132 363-374. (doi:10.1016/j.cell.2007.12.032)

Weigel NL 1996 Steroid hormone receptors and their regulation by phosphorylation. Biochemical Journal 319 657-667.
Wiklund J, Wertz N \& Gorski J 1981 A comparison of estrogen effects on uterine and pituitary growth and prolactin synthesis in F344 and Holtzman rats. Endocrinology 109 1700-1707. (doi:10.1210/ endo-109-5-1700)

Yang G, Rosen DG, Zhang Z, Bast RC Jr, Mills GB, Colacino JA, Mercado-Uribe I \& Liu J 2006 The chemokine growth-regulated oncogene 1 (Gro-1) links RAS signaling to the senescence of stromal fibroblasts and ovarian tumorigenesis. PNAS 103 16472-16477. (doi:10.1073/pnas.0605752103)

Young AR \& Narita M 2009 SASP reflects senescence. EMBO Reports 10 228-230. (doi:10.1038/embor.2009.22)

Zeng YX \& el-Deiry WS 1996 Regulation of p21WAF1/CIP1 expression by p53-independent pathways. Oncogene 12 1557-1564.

Received in final form 13 March 2015

Accepted 19 March 2015

Made available online as an Accepted Preprint

19 March 2015
(C) 2015 Society for Endocrinology Printed in Great Britain
Published by Bioscientifica Ltd. 